\title{
LEVEL II SCOUR ANALYSIS FOR BRIDGE 42 (HARDELMSTR0042) on ELM STREET, crossing COOPER BROOK, HARDWICK, VERMONT
}

U.S. Geological Survey Open-File Report 96-565

Prepared in cooperation with

VERMONT AGENCY OF TRANSPORTATION and

FEDERAL HIGHWAY ADMINISTRATION 


\section{LEVEL II SCOUR ANALYSIS FOR BRIDGE 42 (HARDELMSTR0042) on ELM STREET, crossing COOPER BROOK, HARDWICK, VERMONT \\ By SCOTT A. OLSON}

U.S. Geological Survey Open-File Report 96-565

Prepared in cooperation with

VERMONT AGENCY OF TRANSPORTATION and

FEDERAL HIGHWAY ADMINISTRATION 


\title{
U.S. DEPARTMENT OF THE INTERIOR BRUCE BABBITT, Secretary
}

\author{
U.S. GEOLOGICAL SURVEY \\ Gordon P. Eaton, Director
}

For additional information write to:

District Chief

U.S. Geological Survey 361 Commerce Way

Pembroke, NH 03275-3718
Copies of this report may be purchased from:

U.S. Geological Survey

Branch of Information Services

Open-File Reports Unit

Box 25286

Denver, CO 80225-0286 


\section{CONTENTS}

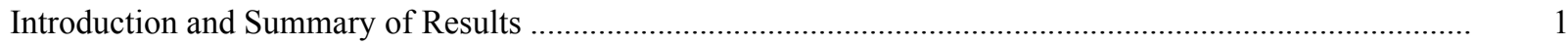

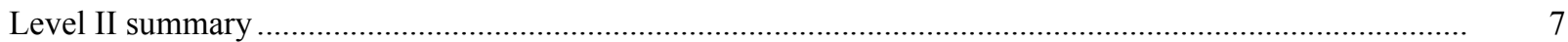

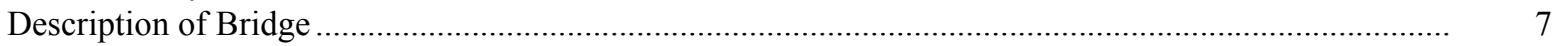

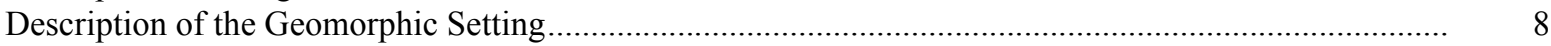

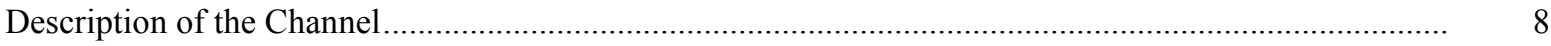

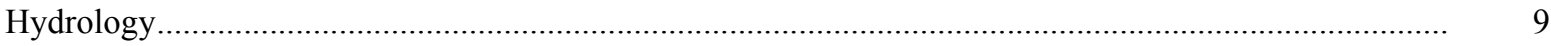

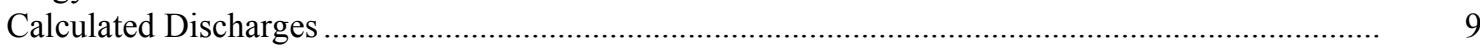

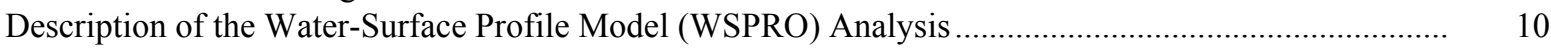

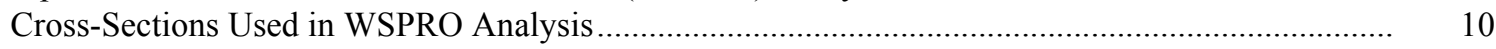

Data and Assumptions Used in WSPRO Model ...................................................................... 11

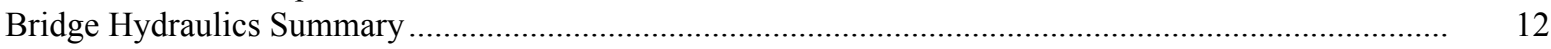

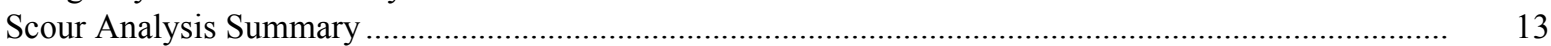

Special Conditions or Assumptions Made in Scour Analysis ...................................................... 13

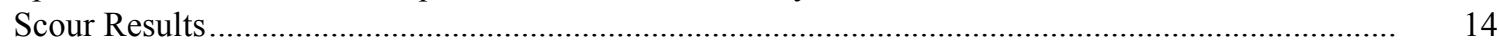

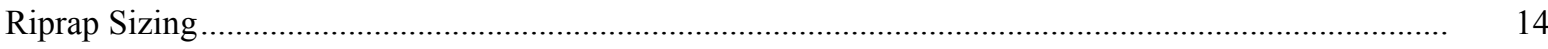

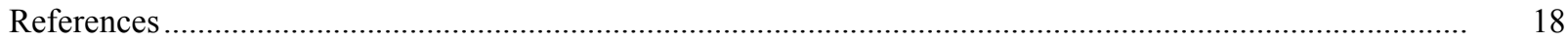

Appendixes:

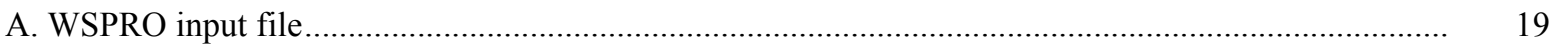

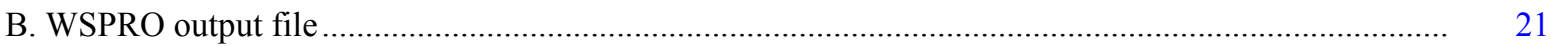

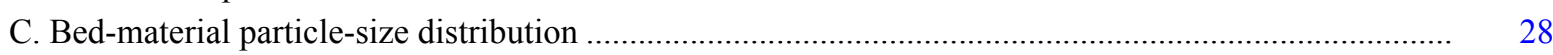

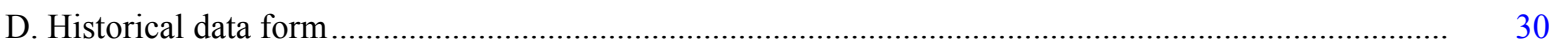

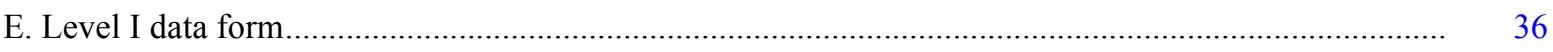

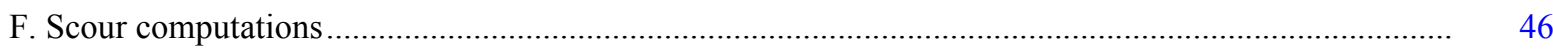

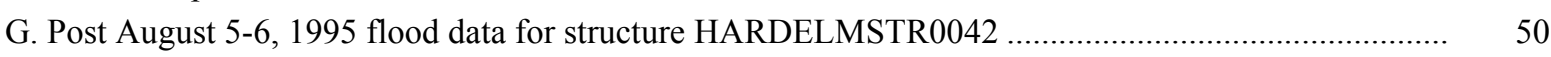

\section{FIGURES}

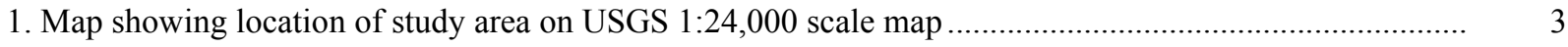

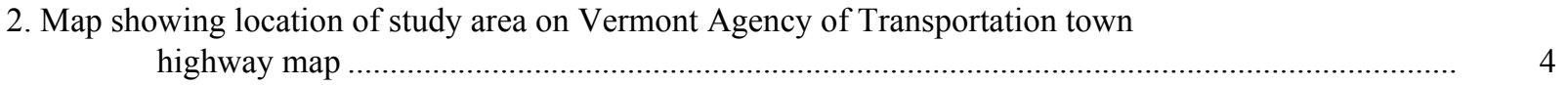

3. Structure HARDELMSTR0042 viewed from upstream (July 24, 1995)............................................ 5

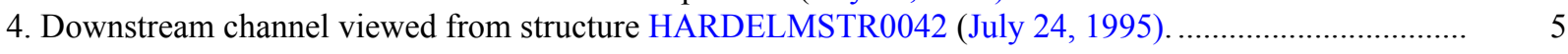

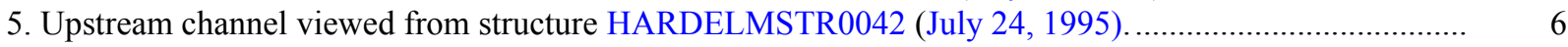

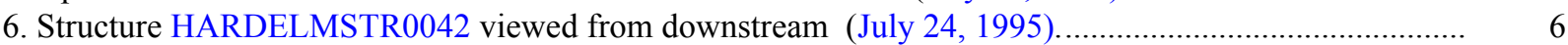

7. Water-surface profiles for the 100- and 500-year discharges at structure

HARDELMSTR0042 on Elm Street, crossing Cooper Brook,

Hardwick, Vermont.

8. Scour elevations for the 100- and 500-year discharges at structure

HARDELMSTR0042 on Elm Street, crossing Cooper Brook,

Hardwick, Vermont.

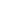

\section{6}

\section{TABLES}

1. Remaining footing/pile depth at abutments for the 100-year discharge at structure

HARDELMSTR0042 on Elm Street, crossing Cooper Brook,

Hardwick, Vermont..

2. Remaining footing/pile depth at abutments for the 500-year discharge at structure

HARDELMSTR0042 on Elm Street, crossing Cooper Brook,

Hardwick, Vermont. 


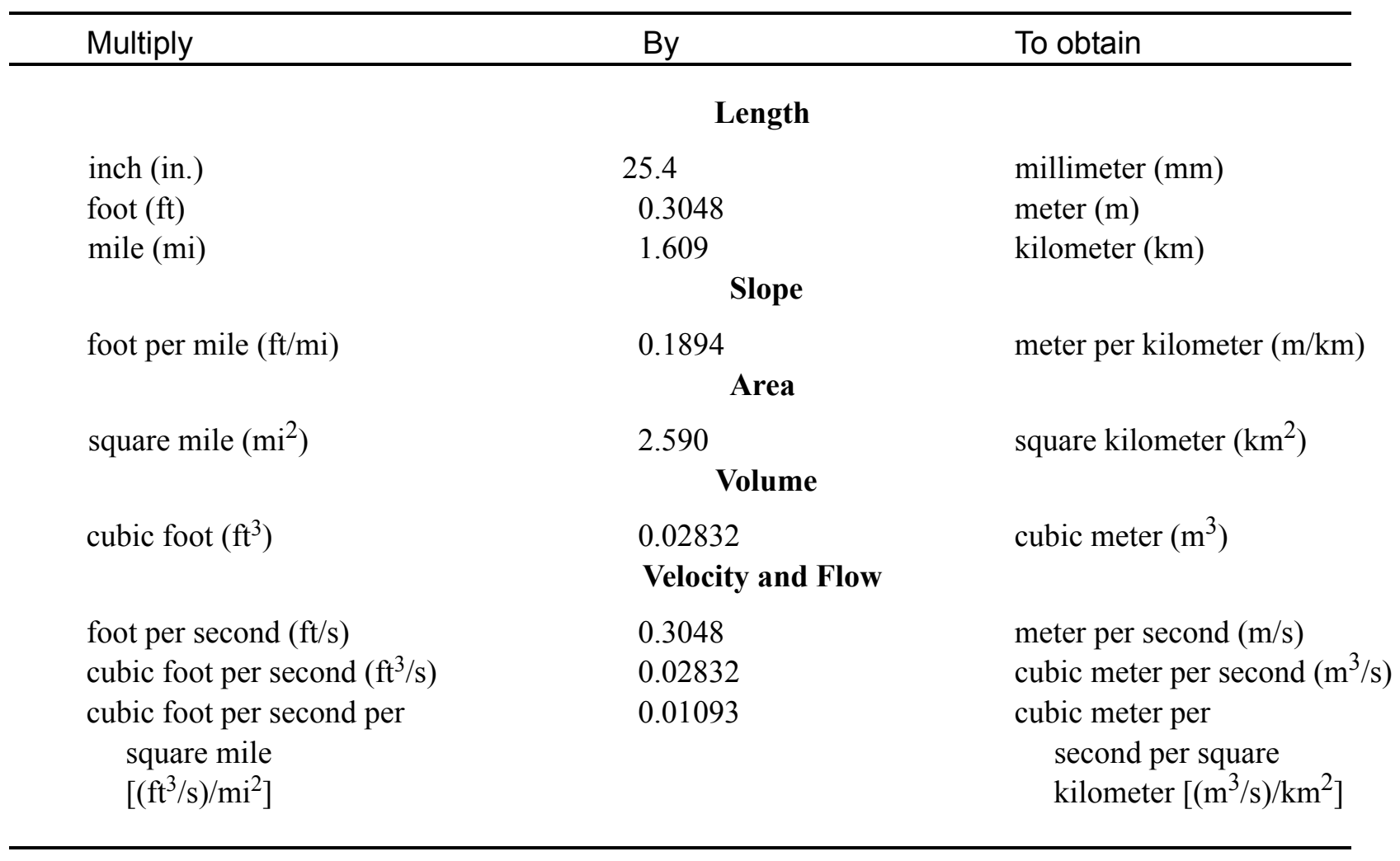

\section{OTHER ABBREVIATIONS}

$\begin{array}{lrlr}\mathrm{BF} & \text { bank full } & \text { LWW } & \text { left wingwall } \\ \mathrm{cfs} & \text { cubic feet per second } & \text { MC } & \text { main channel } \\ \mathrm{D}_{50} & \text { median diameter of bed material } & \text { RAB } & \text { right abutment } \\ \mathrm{DS} & \text { downstream } & \text { RABUT } & \text { face of right abutment } \\ \mathrm{elev} & \text { elevation } & \text { RB } & \text { right bank } \\ \mathrm{f} / \mathrm{p} & \text { flood plain } & \text { ROB } & \text { right overbank } \\ \mathrm{ft}^{2} & \text { square feet } & \text { RWW } & \text { right wingwall } \\ \mathrm{ft} / \mathrm{ft} & \text { feet per foot } & \text { TH } & \text { town highway } \\ \mathrm{JCT} & \text { junction } & \text { UB } & \text { under bridge } \\ \mathrm{LAB} & \text { left abutment } & \text { US } & \text { upstream } \\ \mathrm{LABUT} & \text { face of left abutment } & \text { USGS } & \text { United States Geological Survey } \\ \mathrm{LB} & \text { left bank } & \text { VTAOT Vermont Agency of Transportation } \\ \mathrm{LOB} & \text { left overbank } & \text { WSPRO } & \text { water-surface profile model }\end{array}$

In this report, the words "right" and "left" refer to directions that would be reported by an observer facing downstream. Sea level: In this report, "sea level" refers to the National Geodetic Vertical Datum of 1929-- a geodetic datum derived from a general adjustment of the first-order level nets of the United States and Canada, formerly called Sea Level Datum of 1929.

In the appendices, the above abbreviations may be combined. For example, USLB would represent upstream left bank. 


\title{
LEVEL II SCOUR ANALYSIS FOR BRIDGE 42 (HARDELMSTR0042) ON ELM STREET, CROSSING COOPER BROOK, HARDWICK, VERMONT
}

\author{
By Scott A. Olson
}

\section{INTRODUCTION AND SUMMARY OF RESULTS}

This report provides the results of a detailed Level II analysis of scour potential at structure HARDELMSTR0042 on Elm Street crossing Cooper Brook, Hardwick, Vermont (figures 1-8). A Level II study is a basic engineering analysis of the site, including a quantitative analysis of stream stability and scour (U.S. Department of Transportation, 1993). Results of a Level I scour investigation also are included in Appendix E of this report. A Level I investigation provides a qualitative geomorphic characterization of the study site. Information on the bridge, gleaned from Vermont Agency of Transportation (VTAOT) files, was compiled prior to conducting Level I and Level II analyses and is found in Appendix D.

The site is in the New England Upland section of the New England physiographic province in north-central Vermont. The $16.6-\mathrm{mi}^{2}$ drainage area is in a predominantly rural and forested basin. In the vicinity of the study site, the overbanks are primarily grass covered with some brush along the immediate channel banks except the upstream right bank and overbank which is forested and the downstream left overbank which has a lumberyard.

In the study area, Cooper Brook has a sinuous channel with a slope of approximately 0.005 $\mathrm{ft} / \mathrm{ft}$, an average channel top width of $50 \mathrm{ft}$ and an average channel depth of $6 \mathrm{ft}$. The predominant channel bed materials are sand and gravel with a median grain size $\left(\mathrm{D}_{50}\right)$ of $1.25 \mathrm{~mm}(0.00409 \mathrm{ft})$. The geomorphic assessment at the time of the Level I and Level II site visit on July 24,1995 , indicated that the reach was stable.

The Elm Street crossing of Cooper Brook is a 39-ft-long, two-lane bridge consisting of one 37-foot concrete span (Vermont Agency of Transportation, written communication, March 17, 1995). The bridge is supported by vertical, concrete abutments with wingwalls. The channel is skewed approximately 40 degrees to the opening while the opening-skew-toroadway is 45 degrees.

On August 17, 1995 the site was revisited to investigate the effect of the August 4-5, 1995 flood on the structure. Channel features such as scour holes and point bars were shifted by the high flow event. Details of these changes can be found in the Level I data form in Appendix E. Additional details describing conditions at the site are included in the Level II Summary and Appendices D and G. 
Scour depths and rock rip-rap sizes were computed using the general guidelines described in Hydraulic Engineering Circular 18 (Richardson and others, 1993). Total scour at a highway crossing is comprised of three components: 1) long-term streambed degradation; 2) contraction scour (due to accelerated flow caused by a reduction in flow area at a bridge) and; 3) local scour (caused by accelerated flow around piers and abutments). Total scour is the sum of the three components. Equations are available to compute depths for contraction and local scour and a summary of the results of these computations follows.

Contraction scour for all modelled flows ranged from 0.0 to $3.4 \mathrm{ft}$. The worst-case contraction scour occurred at the incipient-overtopping discharge which was less than the 100-year discharge. Abutment scour ranged from 7.1 to $10.4 \mathrm{ft}$. The worst-case abutment scour occurred at the 500-year discharge. Additional information on scour depths and depths to armoring are included in the section titled "Scour Results". Scoured-streambed elevations, based on the calculated scour depths, are presented in tables 1 and 2. A crosssection of the scour computed at the bridge is presented in figure 8. Scour depths were calculated assuming an infinite depth of erosive material and a homogeneous particle-size distribution.

It is generally accepted that the Froehlich equation (abutment scour) gives "excessively conservative estimates of scour depths" (Richardson and others, 1993, p. 48). Usually, computed scour depths are evaluated in combination with other information including (but not limited to) historical performance during flood events, the geomorphic stability assessment, existing scour protection measures, and the results of the hydraulic analyses. Therefore, scour depths adopted by VTAOT may differ from the computed values documented herein. 


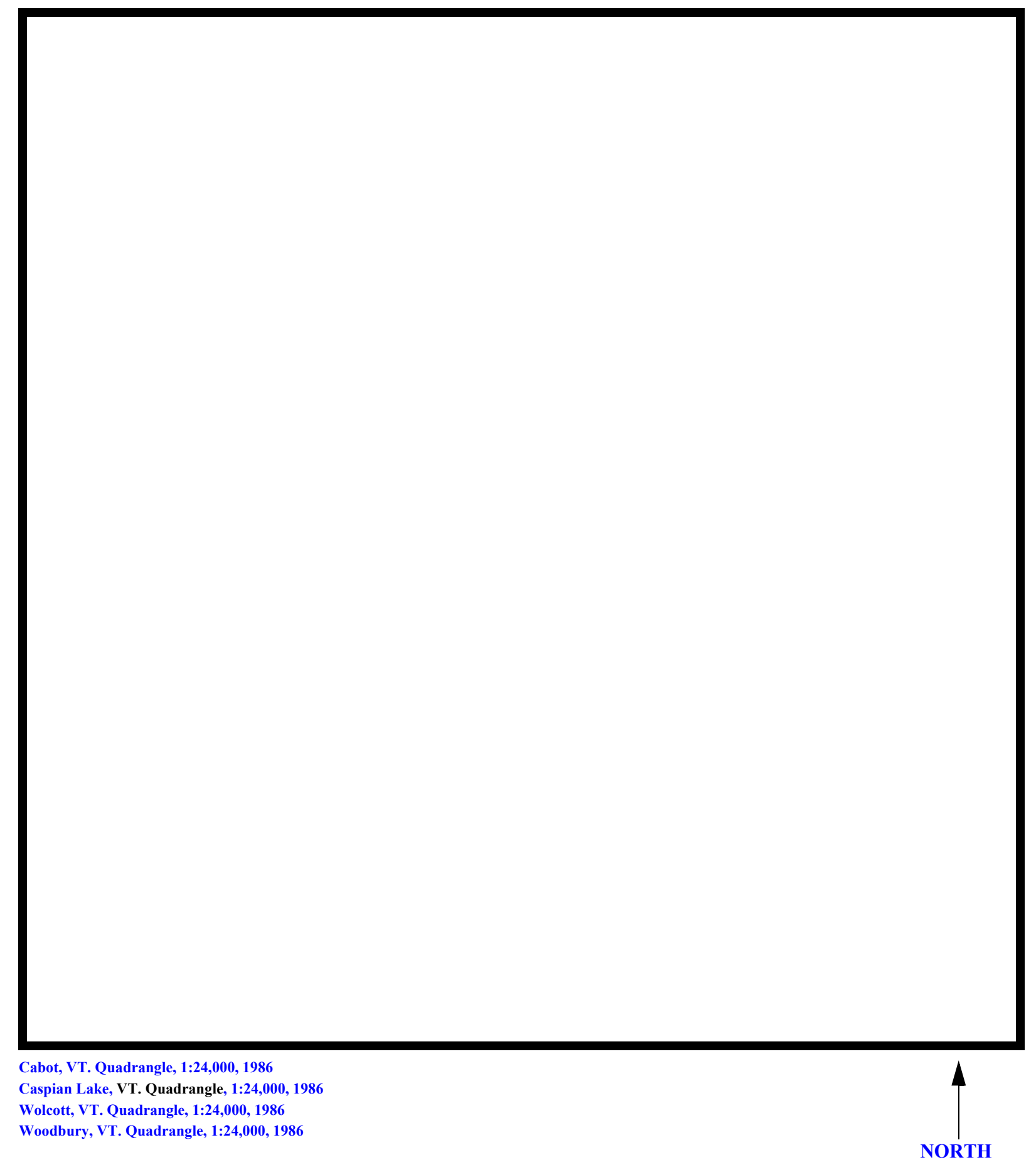

Figure 1. Location of study area on USGS 1:24,000 scale maps. 
Figure 2. Location of study area on Vermont Agency of Transportation town highway map. 

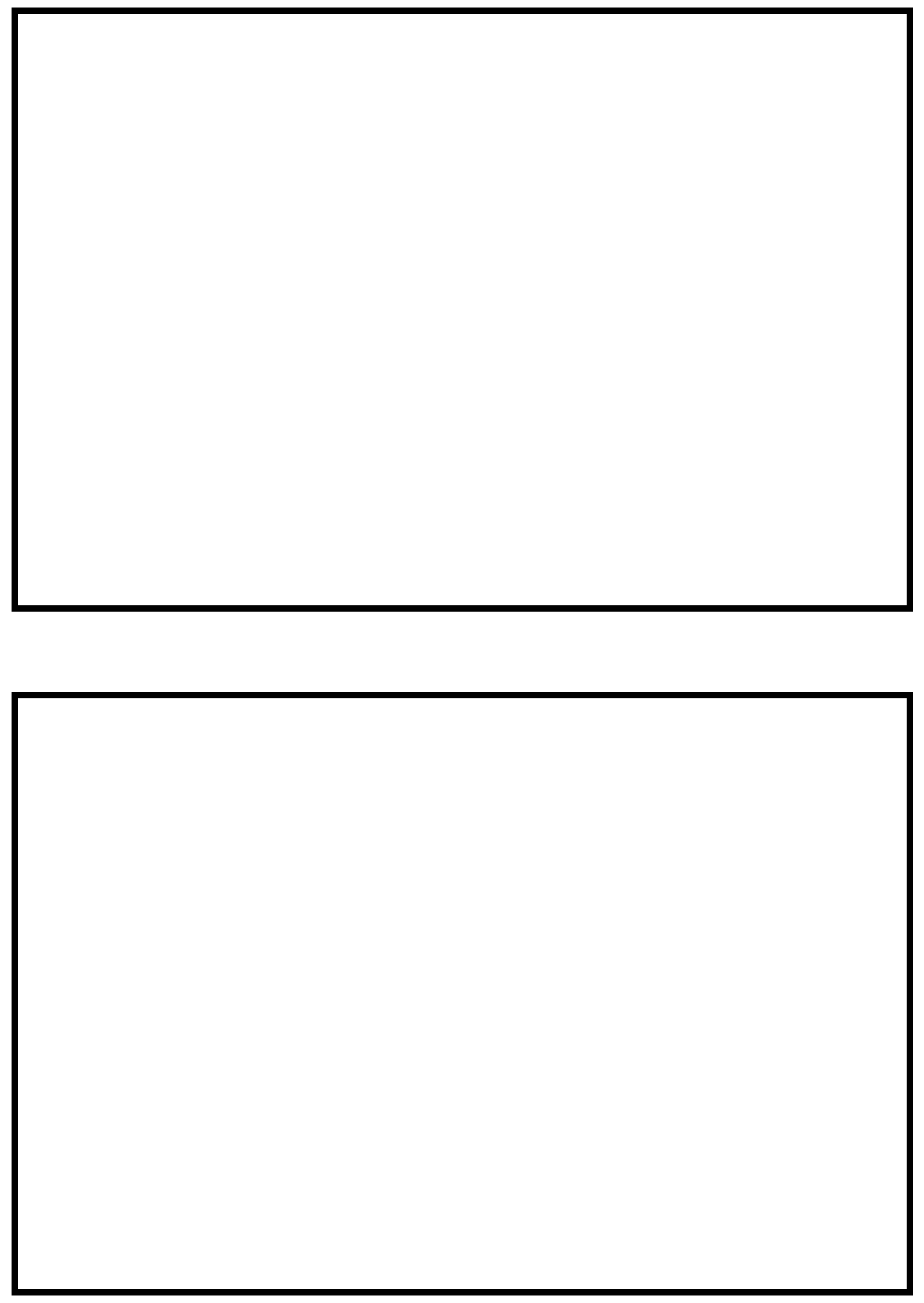

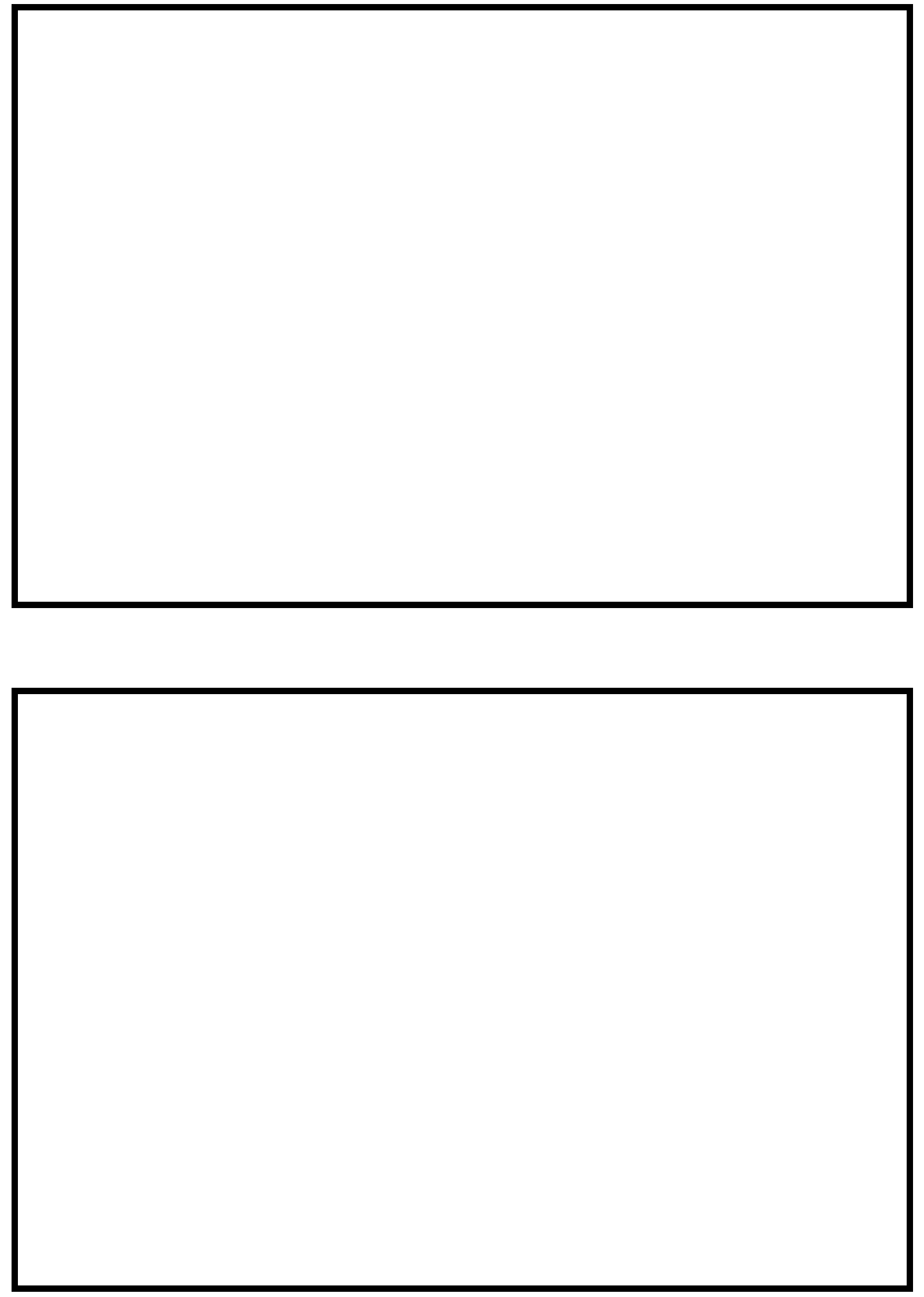


\section{LEVEL II SUMMARY}

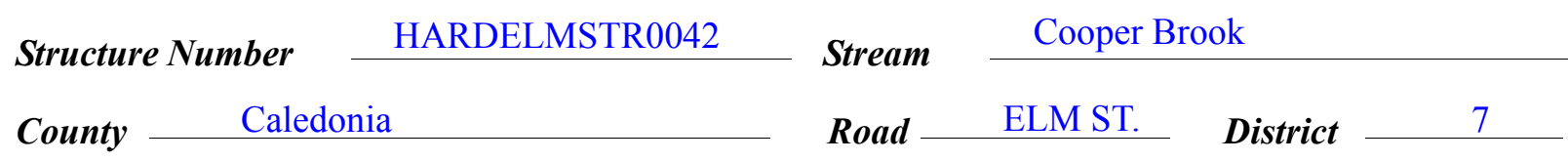

\section{Description of Bridge}

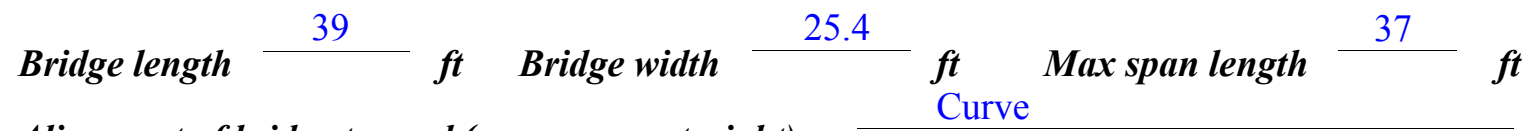

Alignment of bridge to road (on curve or straight)

Abutment type Vertical, concrete

Stone fill on abutment?

$$
\text { Yes }
$$

\section{Embankment type}

$$
\text { Sloping }
$$

$7 / 24 / 95$ and $8 / 17 / 95$

Dato af incnortion Sparse type-2 (less than 36 inches diameter), along both abutments,

upstream wingwalls and the downstream right wingwall.

- . . . . . . . .

\section{$\mathrm{Y}$}

Is bridge skewed to flood flow according to Y r survey? Angle

40

Is bridge skewed to flood flow according to Y r survey? Angle

There is a mild channel bend through reach. The bend ressults in flow impacting the right abutment. $7 / 24 / 95$ and $8 / 17 / 95$

\begin{tabular}{|c|c|c|c|}
\hline & $0^{\text {Dato of insnortion }}$ & $\begin{array}{l}\text { Percent of rhommol } \\
\text { blocked inortzontally }\end{array}$ & $\begin{array}{l}\text { Percent of } 7 / 24 / \\
\text { blocked verticatty }\end{array}$ \\
\hline & 95 & 0 & 0 \\
\hline & Moderate. & & \\
\hline
\end{tabular}

Debris accumulation on bridge at time of Level I or Level II site visit:

\section{Potential for debris}

July 24, 1995 and August 17, 1995. Lumber yard on downstream left bank may be a potential Doscriho anv fonturos noar ar at tho hridos that mav affort flow, (includo ahsorvation dato) source of debris. 


\section{Description of the Geomorphic Setting}

General topography The channel is located within a moderate relief, upland valley with a flat to slightly irregular, flood plain.

Geomorphic conditions at bridge site: downstream (DS), upstream (US)

Date of inspection $\quad 7 / 24 / 95$ and 8/17/95

DS left: $\quad$ Flood plain.

DS right: $\quad$ Narrow flood plain.

US left: $\quad$ Flood plain.

US right: $\quad$ Steeply sloped overbank.

\section{Description of the Channel}

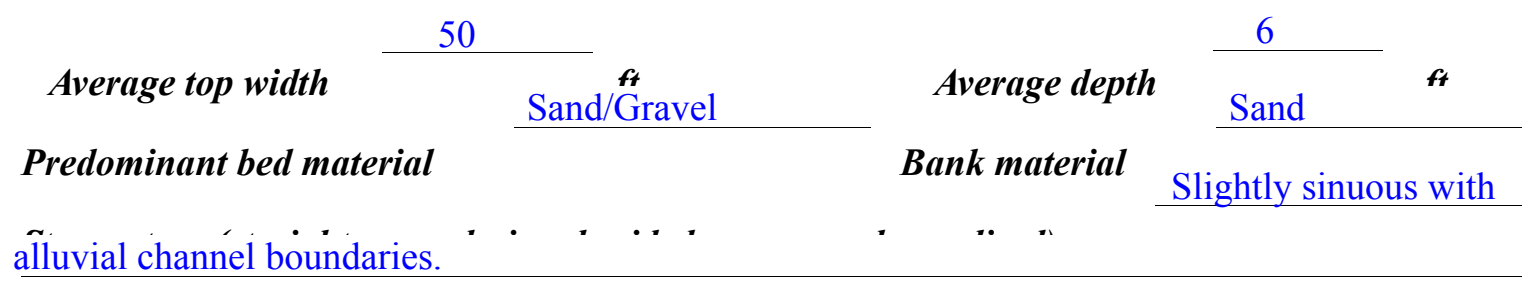

$7 / 24 / 95$ and $8 / 17 / 95$

Vegetative co ${ }^{1}$ Primarily grass with brush on immediate banks. At lumber yard, no cover.

DS left: $\quad$ Primarily grass with brush on immediate banks.

DS right: $\quad$ Primarily grass with brush on immediate banks. At lumber yard, no cover.

US left: $\quad$ Forested

US right: $\quad \underline{\mathrm{Y}}$

Do banks appear stable? Some bank cutting but reach has only a slight bend and banks are considered stable.
date of observation.

July 24, 1995, None;

August 17, 1995, None.

Describe any obstructions in channel and date of observation. 


\section{Hydrology}

Drainage area $\frac{16.6}{\boldsymbol{m i}^{2}}$

Percentage of drainage area in physiographic provinces: (approximate)

Physiographic province/section New England/New England Upland
Percent of drainage area 100

Is drainage area considered rural or urban? Rural _ Describe any significant

urbanization: None.

Is there a USGS gage on the stream of interest?

No

\section{USGS gage description}

USGS gage number

Gage drainage area $\mathrm{mi}^{2}$

No

Is there a lake/p There is a pond upstream at Mackville, but it is considered to have minimal storage effect.

\begin{tabular}{|c|c|c|c|}
\hline 2,300 & & arges & 3,200 \\
\hline$Q 100$ & $f t^{3} / s$ & $Q 500$ & \\
\hline
\end{tabular}

The 100-year discharge is from the VTAOT

database. The 500-year discharge was determined from a graphical extrapolation of the 10-, 25-, 50 -, and 100-year discharges available in the database for bridge 42 . 


\section{Description of the Water-Surface Profile Model (WSPRO) Analysis}

Datum for WSPRO analysis (USGS survey, sea level, VTAOT plans)

USGS survey

Datum tie between USGS survey and VTAOT plans

Add 2.13 feet to USGS survey to

obtain VTAOT plans datum and mean sea level.

Description of reference marks used to determine USGS datum. $\quad$ RM1 is the center of a

brass tablet in the downstream end of the right abutment (elev. $809.44 \mathrm{ft}$, arbitrary survey

datum). RM2 is a chiseled $\mathrm{X}$ on top of the downstream end of the left abutment (elev. $809.16 \mathrm{ft}$,

arbitrary survey datum). RM3 is a chiseled $\mathrm{X}$ in the upstream end of the right abutment (elev.

$809.79 \mathrm{ft}$, arbitrary survey datum).

\section{Cross-Sections Used in WSPRO Analysis}

\begin{tabular}{|c|c|c|c|}
\hline${ }^{1}$ Cross-section & $\begin{array}{c}\text { Section } \\
\text { Reference } \\
\text { Distance } \\
(\text { SRD) in feet }\end{array}$ & $\begin{array}{c}{ }^{2} \text { Cross-section } \\
\text { development }\end{array}$ & Comments \\
\hline EXITX & -49 & 1 & Exit section \\
\hline FULLV & 0 & 2 & $\begin{array}{l}\text { Downstream Full-valley } \\
\text { section (Templated from } \\
\text { EXITX) }\end{array}$ \\
\hline BRIDG & 0 & 1 & Bridge section \\
\hline RDWAY & 20 & 1 & Road Grade section \\
\hline APPRO & 62 & 2 & $\begin{array}{l}\text { Modelled Approach sec- } \\
\text { tion (Templated from } \\
\text { SURVA) }\end{array}$ \\
\hline SURVA & 81 & 1 & $\begin{array}{l}\text { Approach section as sur- } \\
\text { veyed (Used as a tem- } \\
\text { plate) }\end{array}$ \\
\hline
\end{tabular}

${ }^{1}$ For location of cross-sections see plan-view sketch included with Level I field form, Appendix E. For more detail on how cross-sections were developed see WSPRO input file. 


\section{Data and Assumptions Used in WSPRO Model}

Hydraulic analyses of the reach were done by use of the Federal Highway Administration's WSPRO step-backwater computer program (Shearman and others, 1986, and Shearman, 1990). The analyses reported herein reflect conditions existing at the site at the time of the study. Furthermore, in the development of the model it was necessary to assume no accumulation of debris or ice at the site. Results of the hydraulic model are presented in the Bridge Hydraulic Summary, Appendix B, and figure 7.

Channel roughness factors (Manning's “ $n$ ”) used in the hydraulic model were estimated using field inspections at each cross section following the general guidelines described by Arcement and Schneider (1989). Final adjustments to the values were made during the modelling of the reach. Channel " $\mathrm{n}$ " values for the reach ranged from 0.032 to 0.040 , and overbank " $n$ " values ranged from 0.040 to 0.060 .

Normal depth at the exit section (EXITX) was assumed as the starting water surface. This depth was computed by use of the slope-conveyance method outlined in the user's manual for WSPRO (Shearman, 1990). The slope used was $0.0049 \mathrm{ft} / \mathrm{ft}$ which was determined from surveyed thalweg points.

The surveyed approach section (SURVA) was moved along the approach channel slope $(0.011 \mathrm{ft} / \mathrm{ft})$ to establish the modelled approach section (APPRO), one bridge length upstream of the upstream face as recommended by Shearman and others (1986). This approach also provides a consistent method for determining scour variables. 


\section{Bridge Hydraulics Summary}

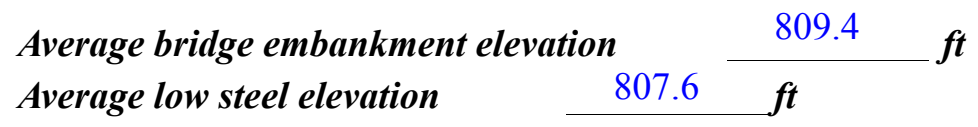

100-year discharge $\quad 2,300 \quad \mathrm{ft}^{3} / \mathrm{s}$

Water-surface elevation in bridge opening $\quad 807.7 \quad f t$

Road overtopping? ___ Y Discharge over road 1,150, s

\begin{tabular}{llll} 
Area of flow in bridge opening & 158 & $\boldsymbol{f t}^{2}$ \\
\cline { 2 - 3 } Average velocity in bridge opening & 7.3 & $\boldsymbol{f t} / \mathrm{s}$
\end{tabular}

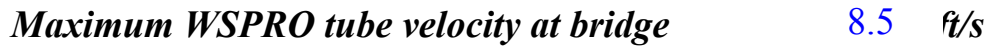

Water-surface elevation at Approach section with bridge 810.8

Water-surface elevation at Approach section without bridge $\quad \frac{810.2}{}$

Amount of backwater caused by bridge $\quad 0.6 \quad$ it

500-year discharge $\quad 3,200 \quad \mathrm{ft}^{3} / \mathrm{s}$

Water-surface elevation in bridge opening $\quad 807.7 \mathrm{ft}$

Road overtopping? ___ Y Discharge over road _ $\quad 2,200^{-}$

Area of flow in bridge opening $\quad 158 \quad \mathrm{ft}^{2}$

Average velocity in bridge opening $6.4 \mathrm{ft} / \mathrm{s}$

Maximum WSPRO tube velocity at bridge 7.4 _s

Water-surface elevation at Approach section with bridge 811.4

Water-surface elevation at Approach section without bridge $\quad 811.0$

Amount of backwater caused by bridge 0.4 .

Incipient overtopping discharge $\quad 1,320 \mathrm{ft}^{3} / \mathrm{s}$

Water-surface elevation in bridge opening $\quad 807.7 \quad t$

Area of flow in bridge opening $\quad 158 \quad \mathrm{ft}^{2}$

$\begin{array}{lll}\text { Average velocity in bridge opening } & 8.4 \quad \mathrm{ft} / \mathrm{s}\end{array}$

Maximum WSPRO tube velocity at bridge $\quad 9.8 \mathrm{ft} / \mathrm{s}$

Water-surface elevation at Approach section with bridge

Water-surface elevation at Approach section without bridge

809.4

Amount of backwater caused by bridge $\quad 1.1$ it 


\section{Scour Analysis Summary}

\section{Special Conditions or Assumptions Made in Scour Analysis}

Scour depths were computed using the general guidelines described in Hydraulic Engineering Circular 18 (Richardson and others, 1993). Scour depths were calculated assuming an infinite depth of erosive material and a homogeneous particle-size distribution. The results of the scour analysis are presented in tables 1 and 2 and a graph of the scour depths is presented in figure 8 .

Contraction scour was computed by use of the live-bed contraction scour equation (Richardson and others, 1993, p. 33, equation 16). For contraction scour computations, the average depth in the contracted section (AREA/TOPWIDTH) is subtracted from the depth of flow computed by the scour equation (Y2) to determine the actual amount of scour. All three discharges resulted in submerged orifice flow. The results of Chang's contraction scour (Richardson and others, 1995, p. 145-146) for these events were also computed and can be found in appendix F. Because the Chang equation for pressure flow scour was derived solely with data for clear-water scour, it is not currently understood how well it would predict in live-bed conditions. Therefore, although pressure flow conditions exist for all three of the modelled flows, the reported scour depths were computed using Laursen's live-bed contraction scour equation. In this case, the incipient road-overflow model resulted in the worst-case contraction scour with a scour depth of $3.4 \mathrm{ft}$. The incipient road-overflow also resulted in the worst-case total scour.

Abutment scour was computed by use of the Froehlich equation (Richardson and others, 1993, p. 49, equation 24). Variables for the Froehlich equation include the Froude number of the flow approaching the embankments, the length of the embankment blocking flow, and the depth of flow approaching the embankment less any roadway overtopping. 


\section{Scour Results}

100-yr discharge 500-yr discharge

Incipient

overtopping

Contraction scour:

(Scour depths in feet)

Main channel

Live-bed scour

1.0

Clear-water scour

Depth to armoring

Left overbank

Right overbank

Local scour:

Abutment scour

Left abutment

Right abutment

Pier scour

Pier 1

Pier 2

Pier 3
9.5

7.1-
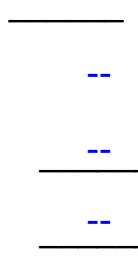

10.4

7.3-

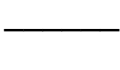

--
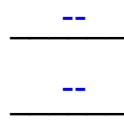

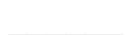

3.4

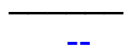

$\mathrm{N} / \mathrm{A}^{-}$

--

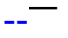

\section{Riprap Sizing}

Incipient overtopping 100-yr discharge 500-yrdischarge discharge

\section{Abutments:}

Left abutment

Right abutment

Piers:

Pier 1

Pier 2 


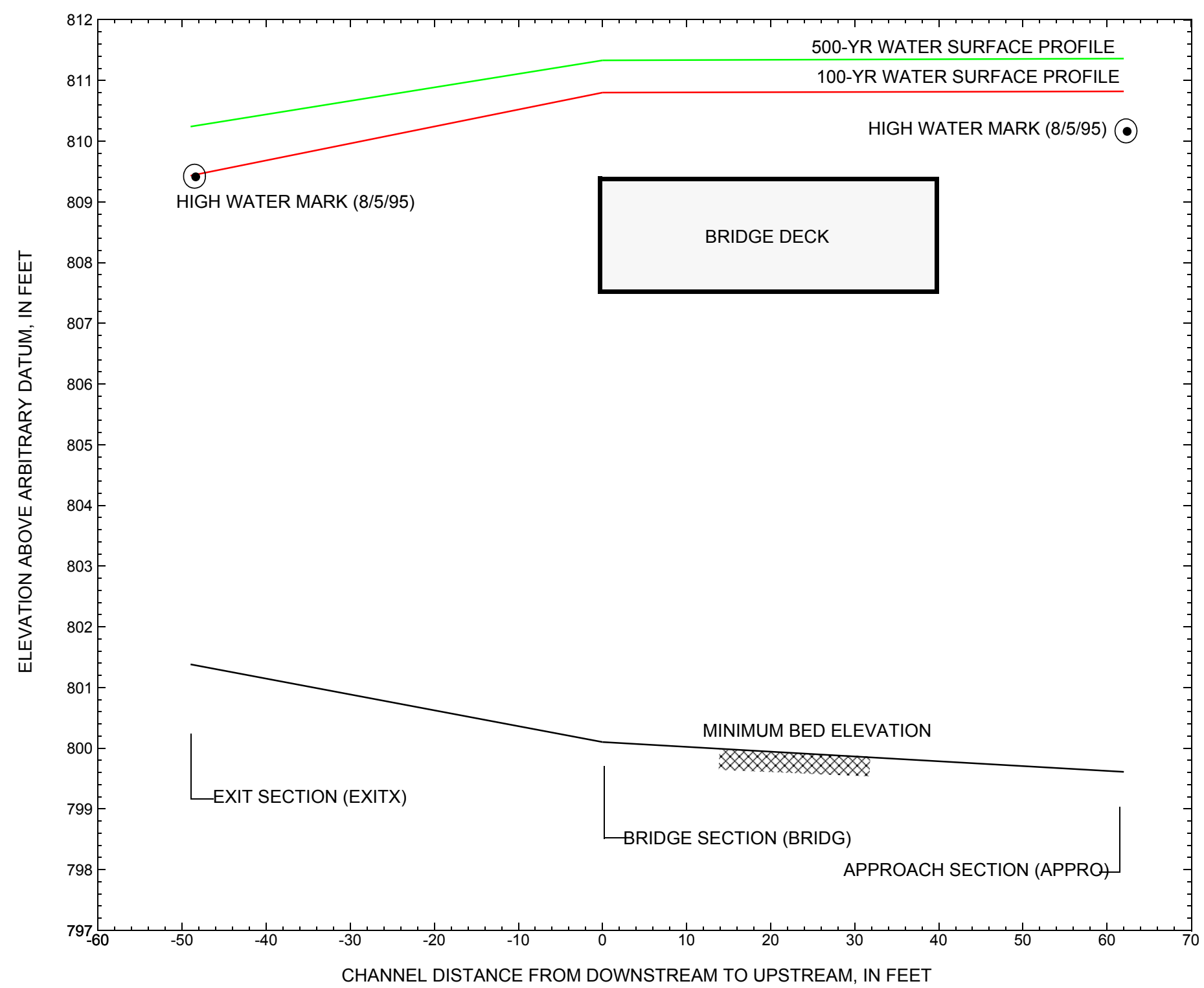

Figure 7. Water-surface profiles for the 100- and 500-yr discharges at structure HARDELMSTR0042 on Elm Street, crossing Cooper Brook, Hardwick, Vermont. 


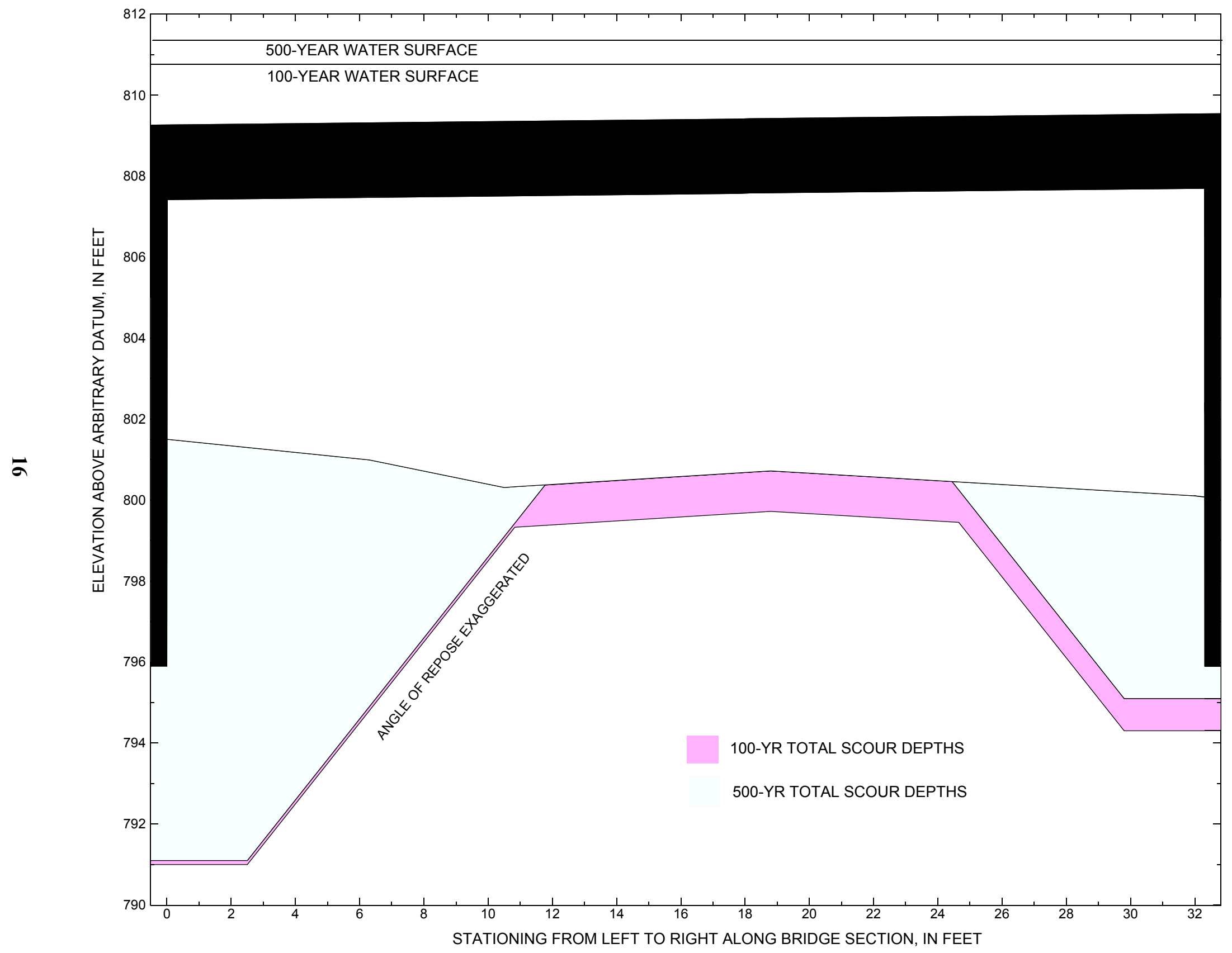

Figure 8. Scour elevations for the 100-yr and 500-yr discharges at structure HARDELMSTR0042 on Elm Street, crossing Cooper Brook, Hardwick, Vermont. 
Table 1. Remaining footing/pile depth at abutments for the 100-year discharge at structure HARDELMSTR0042 on Elm Street, crossing Cooper Brook, Hardwick, Vermont. [VTAOT, Vermont Agency of Transportation; --,no data]

\begin{tabular}{|c|c|c|c|c|c|c|c|c|c|c|c|}
\hline Description & Station $^{1}$ & $\begin{array}{l}\text { VTAOT } \\
\text { minimum } \\
\text { bridge seat } \\
\text { elevation } \\
\text { (feet) }\end{array}$ & $\begin{array}{l}\text { Surveyed } \\
\text { minimum } \\
\text { low-chord } \\
\text { elevation } \\
\text { (feet) }\end{array}$ & $\begin{array}{l}\text { Bottom of } \\
\text { footing } \\
\text { elevation } \\
\text { (feet) }\end{array}$ & $\begin{array}{c}\text { Channel } \\
\text { elevation at } \\
\text { abutment/ } \\
\text { pier }^{2} \\
\text { (feet) }\end{array}$ & $\begin{array}{l}\text { Contraction } \\
\text { scour depth } \\
\text { (feet) }\end{array}$ & $\begin{array}{l}\text { Abutment } \\
\text { scour } \\
\text { depth } \\
\text { (feet) }\end{array}$ & $\begin{array}{l}\text { Pier } \\
\text { scour } \\
\text { depth } \\
\text { (feet) }\end{array}$ & $\begin{array}{l}\text { Depth of } \\
\text { total scour } \\
\text { (feet) }\end{array}$ & $\begin{array}{c}\text { Elevation of } \\
\text { scour }^{2} \\
\text { (feet) }\end{array}$ & $\begin{array}{c}\text { Remaining } \\
\text { footing/pile } \\
\text { depth } \\
\text { (feet) }\end{array}$ \\
\hline \multicolumn{12}{|c|}{100 -yr. discharge is 2,300 cubic-feet per second } \\
\hline Left abutment & 0.0 & 809.04 & 807.42 & 795.9 & 801.5 & 1.0 & 9.5 & -- & 10.5 & 791.0 & -4.9 \\
\hline Right abutment & 32.3 & 809.26 & 807.70 & 795.9 & 802.4 & 1.0 & 7.1 & -- & 8.1 & 794.3 & -1.6 \\
\hline
\end{tabular}

1.Measured along the face of the most constricting side of the bridge.

2.Arbitrary datum for this study.

Table 2. Remaining footing/pile depth at abutments for the 500-year discharge at structure HARDELMSTR0042 on Elm Street, crossing Cooper Brook, Hardwick, Vermont. [VTAOT, Vermont Agency of Transportation; --, no data]

\begin{tabular}{|c|c|c|c|c|c|c|c|c|c|c|c|}
\hline Description & Station $^{1}$ & $\begin{array}{l}\text { VTAOT } \\
\text { minimum } \\
\text { bridge seat } \\
\text { elevation } \\
\text { (feet) }\end{array}$ & $\begin{array}{l}\text { Surveyed } \\
\text { minimum } \\
\text { low-chord } \\
\text { elevation } \\
\text { (feet) }\end{array}$ & $\begin{array}{c}\text { Bottom of } \\
\text { footing } \\
\text { elevation } \\
\text { (feet) }\end{array}$ & $\begin{array}{c}\text { Channel } \\
\text { elevation at } \\
\text { abutment/ } \\
\text { pier }^{2} \\
\text { (feet) }\end{array}$ & $\begin{array}{l}\text { Contraction } \\
\text { scour depth } \\
\text { (feet) }\end{array}$ & $\begin{array}{l}\text { Abutment } \\
\text { scour } \\
\text { depth } \\
\text { (feet) }\end{array}$ & $\begin{array}{l}\text { Pier } \\
\text { scour } \\
\text { depth } \\
\text { (feet) }\end{array}$ & $\begin{array}{l}\text { Depth of } \\
\text { total scour } \\
\text { (feet) }\end{array}$ & $\begin{array}{c}\text { Elevation of } \\
\text { scour }^{2} \\
\text { (feet) }\end{array}$ & $\begin{array}{c}\text { Remaining } \\
\text { footing/pile } \\
\text { depth } \\
\text { (feet) }\end{array}$ \\
\hline \multicolumn{12}{|c|}{500 -yr. discharge is 3,200 cubic-feet per second } \\
\hline Left abutment & 0.0 & 809.04 & 807.42 & 795.9 & 801.5 & 0.0 & 10.4 & -- & 10.4 & 791.1 & -4.8 \\
\hline Right abutment & 32.3 & 809.26 & 807.70 & 795.9 & 802.4 & 0.0 & 7.3 & -- & 7.3 & 795.1 & -0.8 \\
\hline
\end{tabular}

1.Measured along the face of the most constricting side of the bridge.

2.Arbitrary datum for this study. 


\section{SELECTED REFERENCES}

Arcement, G.J., Jr., and Schneider, V.R., 1989, Guide for selecting Manning's roughness coefficients for natural channels and flood plains: U.S. Geological Survey Water-Supply Paper 2339, 38 p.

Barnes, H.H., Jr., 1967, Roughness characteristics of natural channels: U.S. Geological Survey Water-Supply Paper 1849, 213 p.

Benson, M. A., 1962, Factors Influencing the Occurrence of Floods in a Humid Region of Diverse Terrain: U.S. Geological Survey Water-Supply Paper 1580B, $64 \mathrm{p}$.

Brown, S.A. and Clyde, E.S., 1989, Design of riprap revetment: Federal Highway Administration Hydraulic Engineering Circular No. 11, Publication FHWAIP-89-016, $156 \mathrm{p}$.

Federal Highway Administration, 1983, Runoff estimates for small watersheds and development of sound design: Federal Highway Administration Report FHWA-RD-77-158

Federal Emergency Management Agency, 1987, Flood Insurance Study, Town of Hardwick, Caledonia County, Vermont: Washington, D.C., January 16, 1987.

Froehlich, D.C., 1989, Local scour at bridge abutments in Ports, M.A., ed., Hydraulic Engineering--Proceedings of the 1989 National Conference on Hydraulic Engineering: New York, American Society of Civil Engineers, p. 13-18.

Hayes, D.C.,1993, Site selection and collection of bridge-scour data in Delaware, Maryland, and Virginia: U.S. Geological Survey Water-Resources Investigation Report 93-4017, 23 p.

Johnson, C.G. and Tasker, G.D.,1974, Progress report on flood magnitude and frequency of Vermont streams: U.S. Geological Survey Open-File Report 74-130, $37 \mathrm{p}$.

Lagasse, P.F., Schall, J.D., Johnson, F., Richardson, E.V., Richardson, J.R., Chang, F., 1993, Stream Stability at Highway Structures: Federal Highway Administration Hydraulic Engineering Circular No. 20, Publication FHWA-IP-90-014, 195 p.

Laursen, E.M., 1960, Scour at bridge crossings: Journal of the Hydraulics Division, American Society of Civil Engineers, v. 86, no. HY2, p. $39-53$.

Potter, W. D., 1957a, Peak rates of runoff in the Adirondack, White Mountains, and Maine woods area, Bureau of Public Roads

Potter, W. D., 1957b, Peak rates of runoff in the New England Hill and Lowland area, Bureau of Public Roads

Richardson, E.V. and Davis, S.R., 1995, Evaluating scour at bridges: Federal Highway Administration Hydraulic Engineering Circular No. 18, Publication FHWA-IP-90-017, $204 \mathrm{p}$.

Richardson, E.V., Harrison, L.J., Richardson, J.R., and Davis, S.R., 1993, Evaluating scour at bridges: Federal Highway Administration Hydraulic Engineering Circular No. 18, Publication FHWA-IP-90-017, 129 p.

Richardson, E.V., Simons, D.B., and Julien, P.Y., 1990, Highways in the river environment: Federal Highway Administration Publication FHWA-HI-90-016.

Ritter, D.F., 1984, Process Geomorphology: W.C. Brown Co., Debuque, Iowa, 603 p.

Shearman, J.O., 1990, User's manual for WSPRO--a computer model for water surface profile computations: Federal Highway Administration Publication FHWA-IP-89-027, 187 p.

Shearman, J.O., Kirby, W.H., Schneider, V.R., and Flippo, H.N., 1986, Bridge waterways analysis model; research report: Federal Highway Administration Publication FHWA-RD-86-108, 112 p.

Talbot, A.N., 1887, The determination of water-way for bridges and culverts.

U.S. Department of Transportation, 1993, Stream stability and scour at highway bridges, Participant Workbook: Federal Highway Administration Publication FHWA HI-91-011.

U.S. Geological Survey, 1986, Cabot, Vermont 7.5 Minute Series quadrangle map: U.S. Geological Survey Topographic Maps, Scale 1:24,000.

U.S. Geological Survey, 1986, Caspian Lake, Vermont 7.5 Minute Series quadrangle map: U.S. Geological Survey Topographic Maps, Scale 1:24,000.

U.S. Geological Survey, 1986, Wolcott, Vermont 7.5 Minute Series quadrangle map: U.S. Geological Survey Topographic Maps, Scale 1:24,000.

U.S. Geological Survey, 1986, Woodbury, Vermont 7.5 Minute Series quadrangle map: U.S. Geological Survey Topographic Maps, Scale 1:24,000. 


\section{APPENDIX A: \\ WSPRO INPUT FILE}




\section{WSPRO INPUT FILE}

GR

GR

GR

GR

$\mathrm{N}$

SA

XS

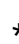

*

*

*
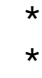

BR

GR

GR

GR

$\mathrm{N}$

CD

*

$\mathrm{XR}$

GR

GR

GR

BP

*

U.S. GEOLOGICAL SURVEY WSPRO INPUT FILE hard042.wsP CREATED ON 14-AUG-95 FOR BRIDGE HARDELMST0042 USING FILE hard042.dca HYDRAULIC ANALYSIS OF HARDO42 SAO

* * 0.002

$6293055255355151617 \quad 13 \quad 3 * 1514 \quad 23 \quad 2111 \quad 124473$

$23003200 \quad 1324$

$0.00490 .0049 \quad 0.0049$

The following commented data is the pre-flood exit section data...

$\begin{array}{lllll}-70.5,809.68 & -21.0,809.20 & -12.0,807.02 & -5.2,804.49\end{array}$

$0.0,802.30 \quad 2.3,801.22$

$23.0,802.30$

$7.3,800.09$

$11.6,800.64$

$17.3,801.27$

$62.7,809.26$

$26.7,804.01$

$37.0,808.45$

$174.6,817.39$

$92.2,809.39$

$29.2,804.91$

$117.3,812.62$

EXITX -49

$-300.0,811.94$

$-70.5,809.68$

$0.0,801.89$

$-21.0,809.20$

$-12.0,807.60$

$-5.2,804.76$

$2.3,801.38$

$7.3,801.43$

$11.6,801.63$

$17.3,801.66$

$23.0,802.30$

$26.7,804.01$

$29.2,804.91$

$37.0,808.45$

$62.7,809.26$

$92.2,809.39$

$105.3,808.00$

$117.3,812.62$

0.060

$174.6,817.39$

0.040

0.040

37

FULLV 0

The following commented data is the pre-flood $x$-section data for the bridge...

$\begin{array}{rrrr}0.0,807.37 & 0.0,804.26 & 6.3,802.32 & 10.5,801.37 \\ 18.8,800.67 & 26.9,800.41 & 32.1,800.67 & 32.3,802.36 \\ 32.3,807.62 & 0.0,807.37 & & \end{array}$

BRIDG $\quad 0 \quad 807.5 \quad 45$

$0.0,807.42$

$0.0,801.48$

$6.3,800.99$

$10.5,800.31$

$18.8,800.72$

$26.9,800.34$

$32.1,800.10$

$32.3,802.36$

$32.3,807.70$

$0.0,807.42$

0.032

$150.5 * * 42.510 .4$

RDWAY $20 \quad 25.4 \quad 2$

$-300.0,812.20$

$-151.8,810.46$

$-110.0,809.97$

$0.0,809.28$

$31.9,809.51$

$63.8,809.87$

$89.8,810.09$

$91.0,813.14$

$108.0,822.29$

$$
0
$$

The following commented data is the pre-flood $\mathrm{x}$-section data for the approach...

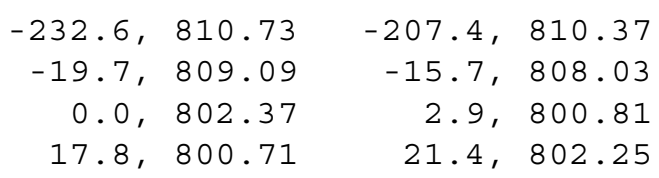

$$
\begin{array}{r}
-93.3,809.45 \\
-6.0,804.33 \\
6.9,800.52 \\
23.2,803.08
\end{array}
$$




\section{WSPRO INPUT FILE (continued)}

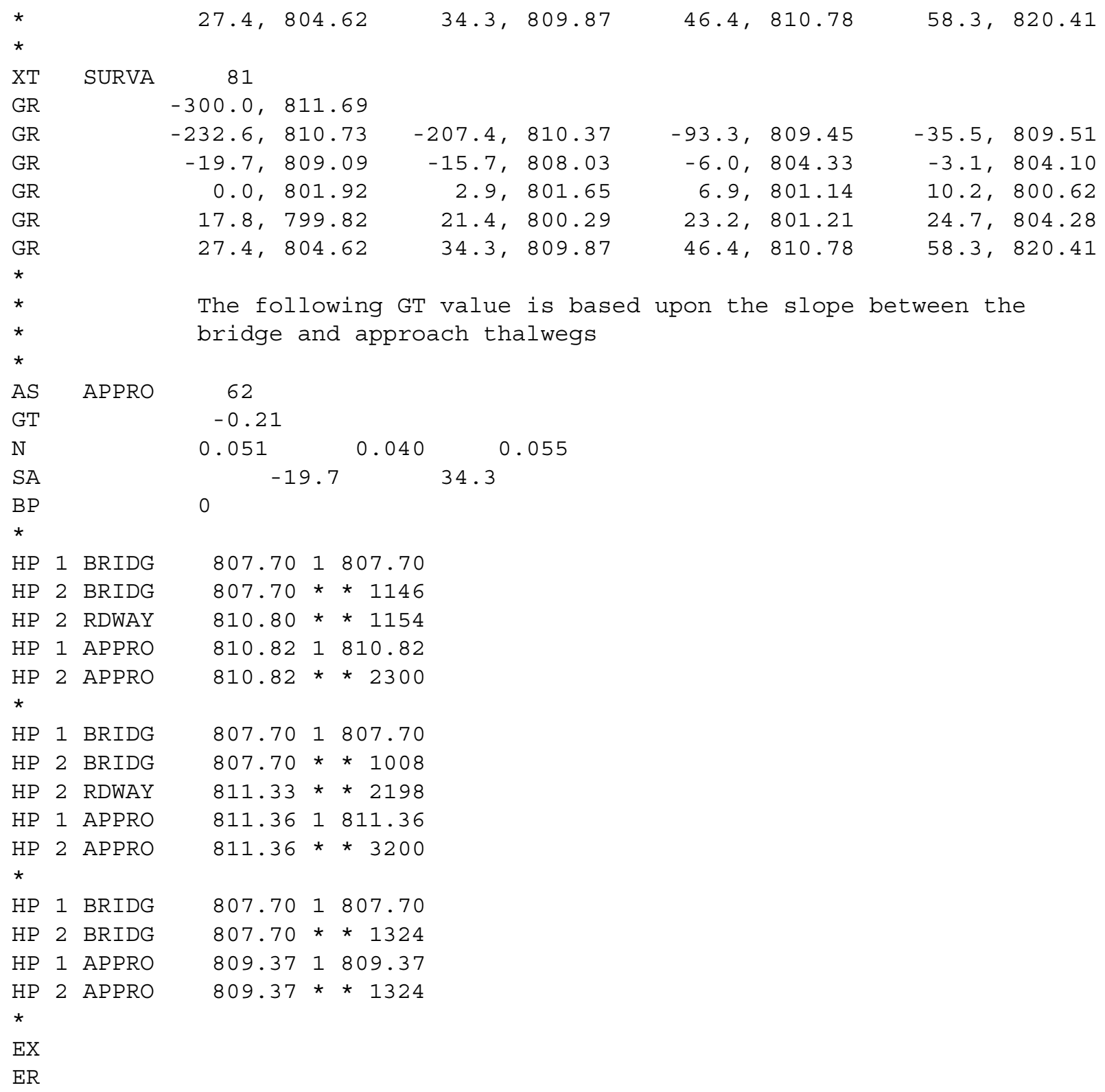




\section{APPENDIX B: \\ WSPRO OUTPUT FILE}




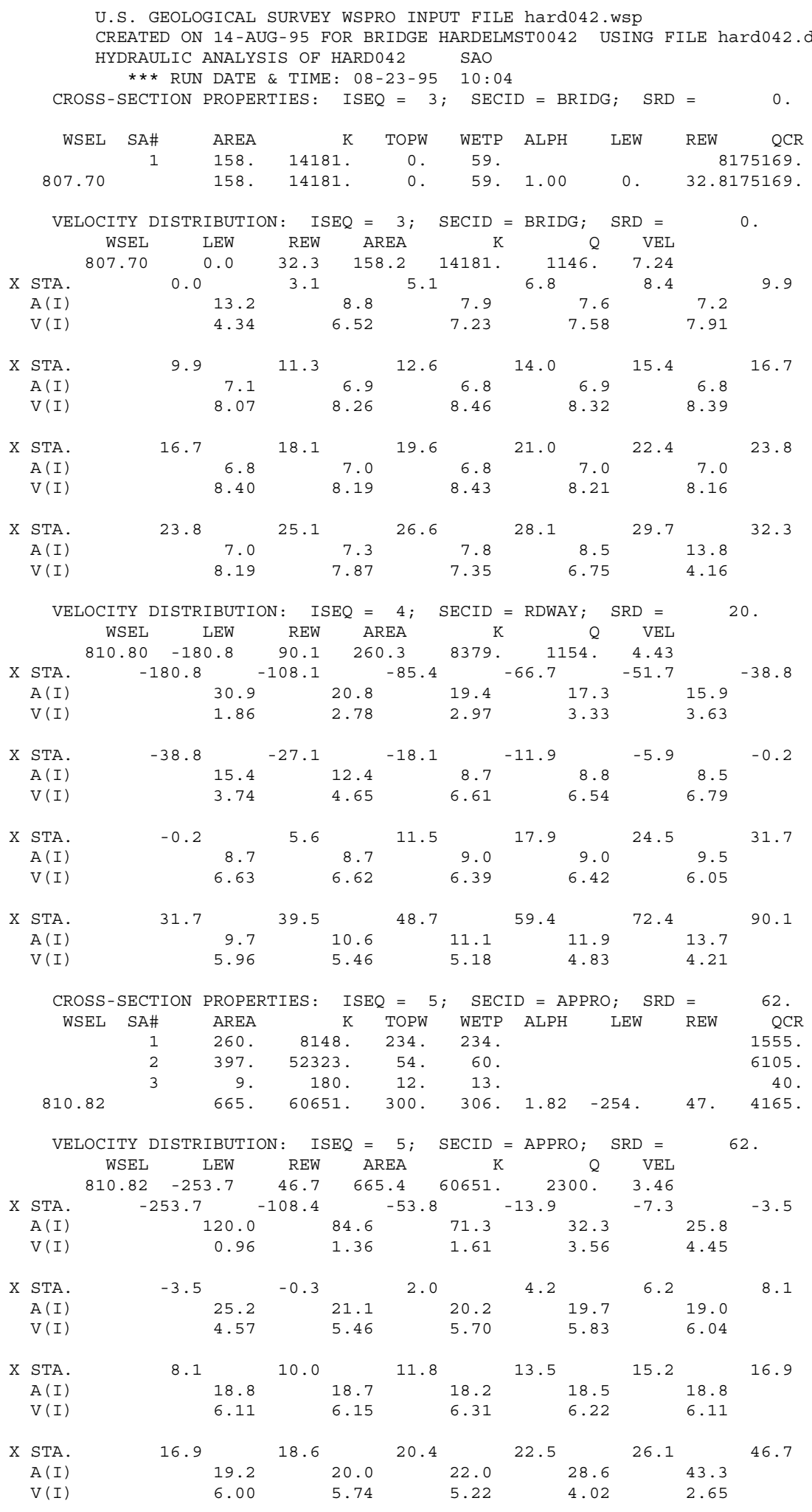


WSPRO OUTPUT FILE (continued)

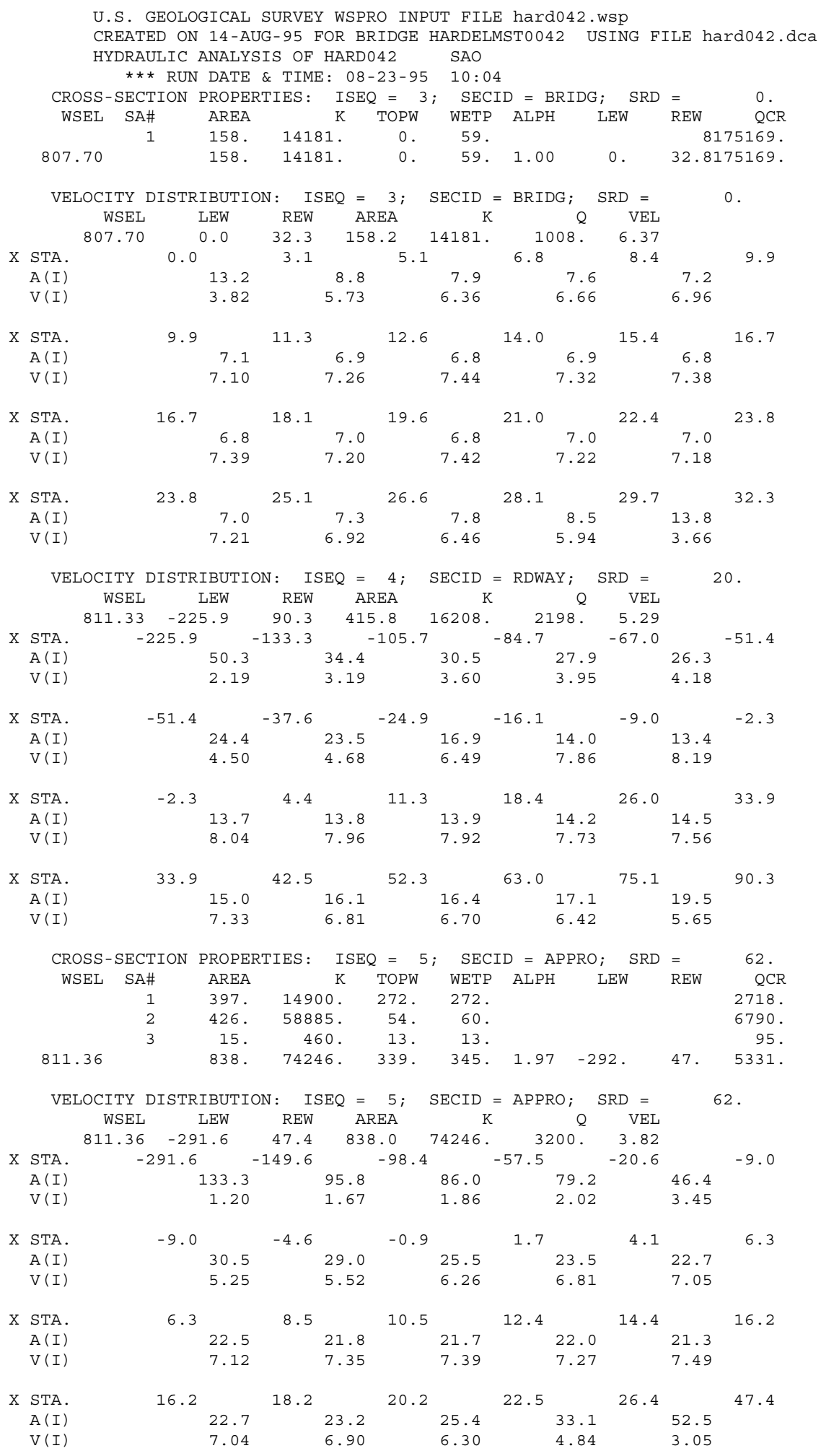


WSPRO OUTPUT FILE (continued)

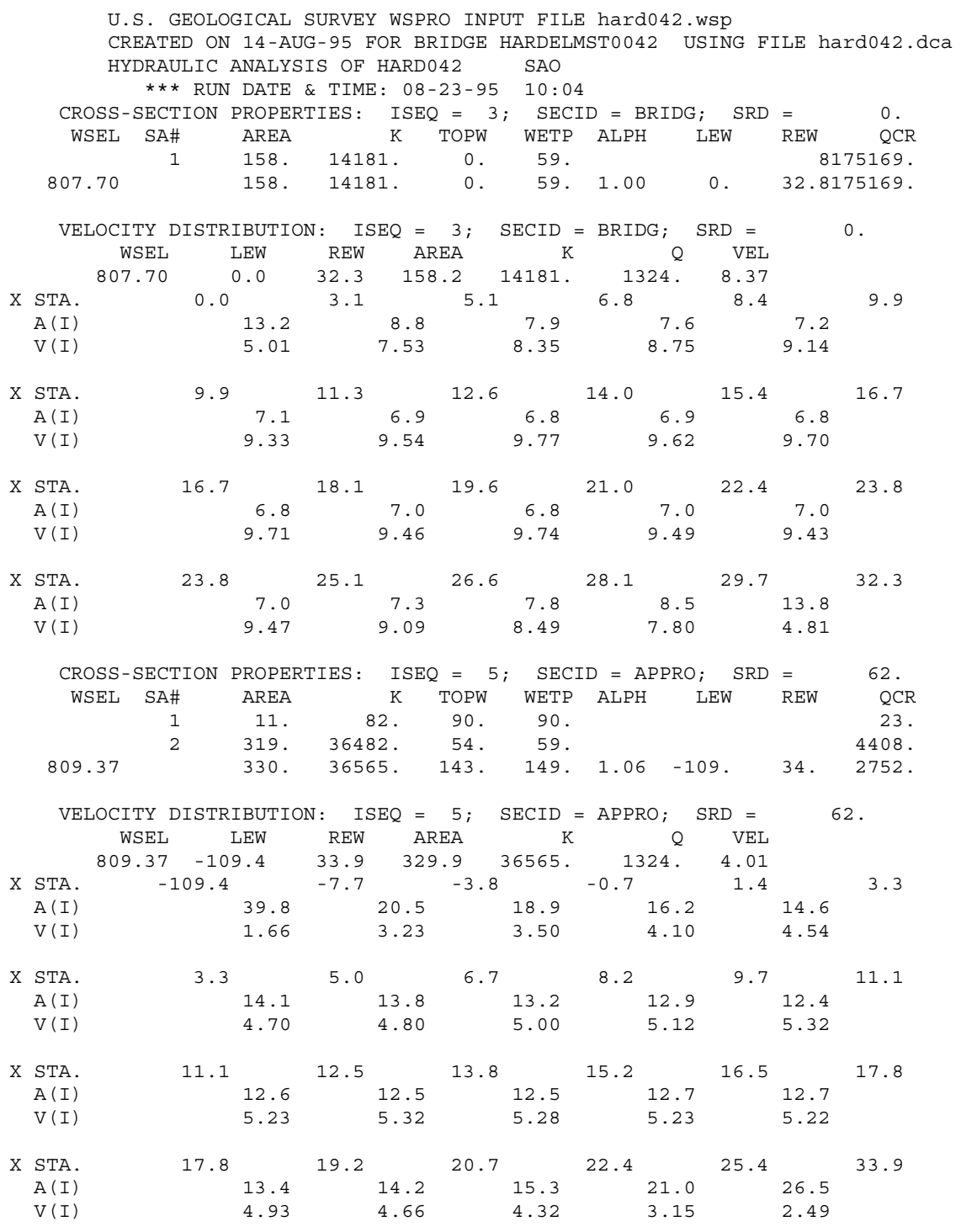


WSPRO OUTPUT FILE (continued)

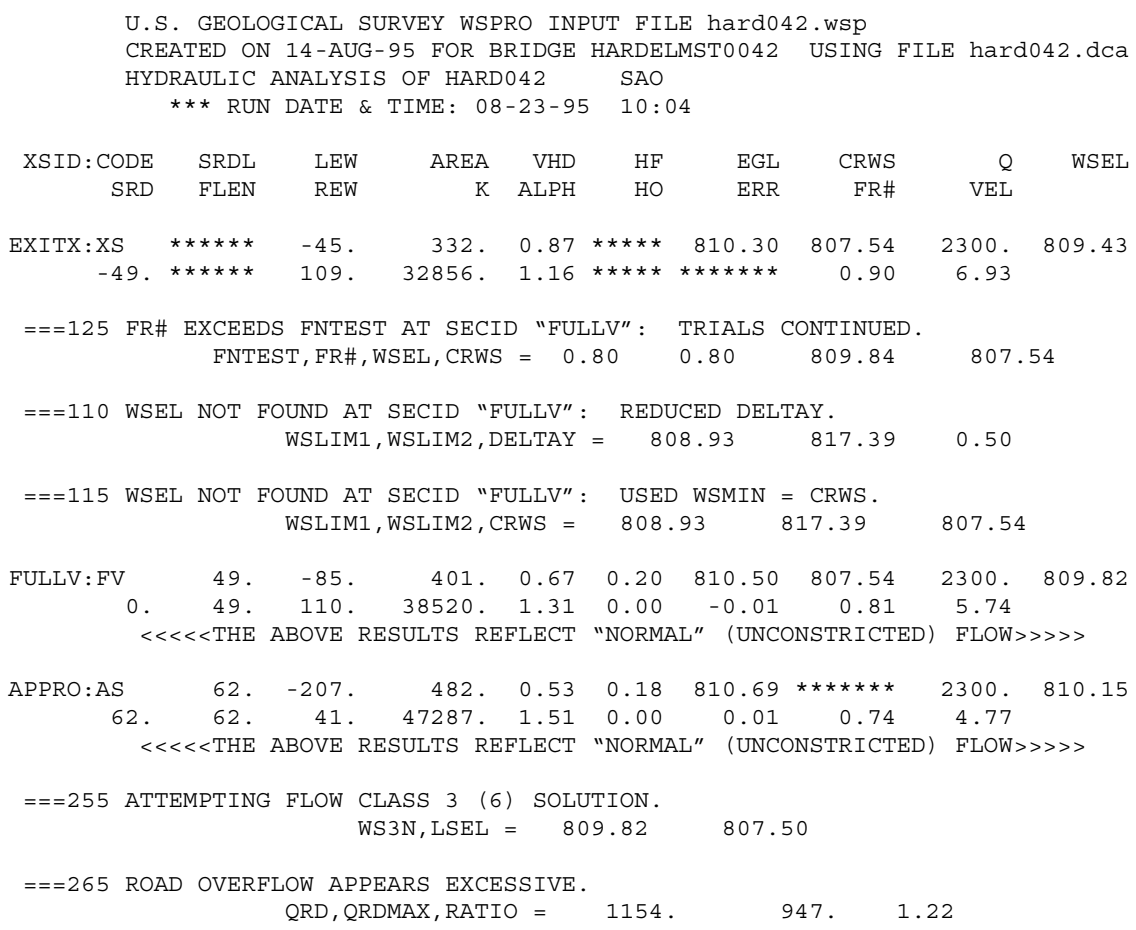


WSPRO OUTPUT FILE (continued)

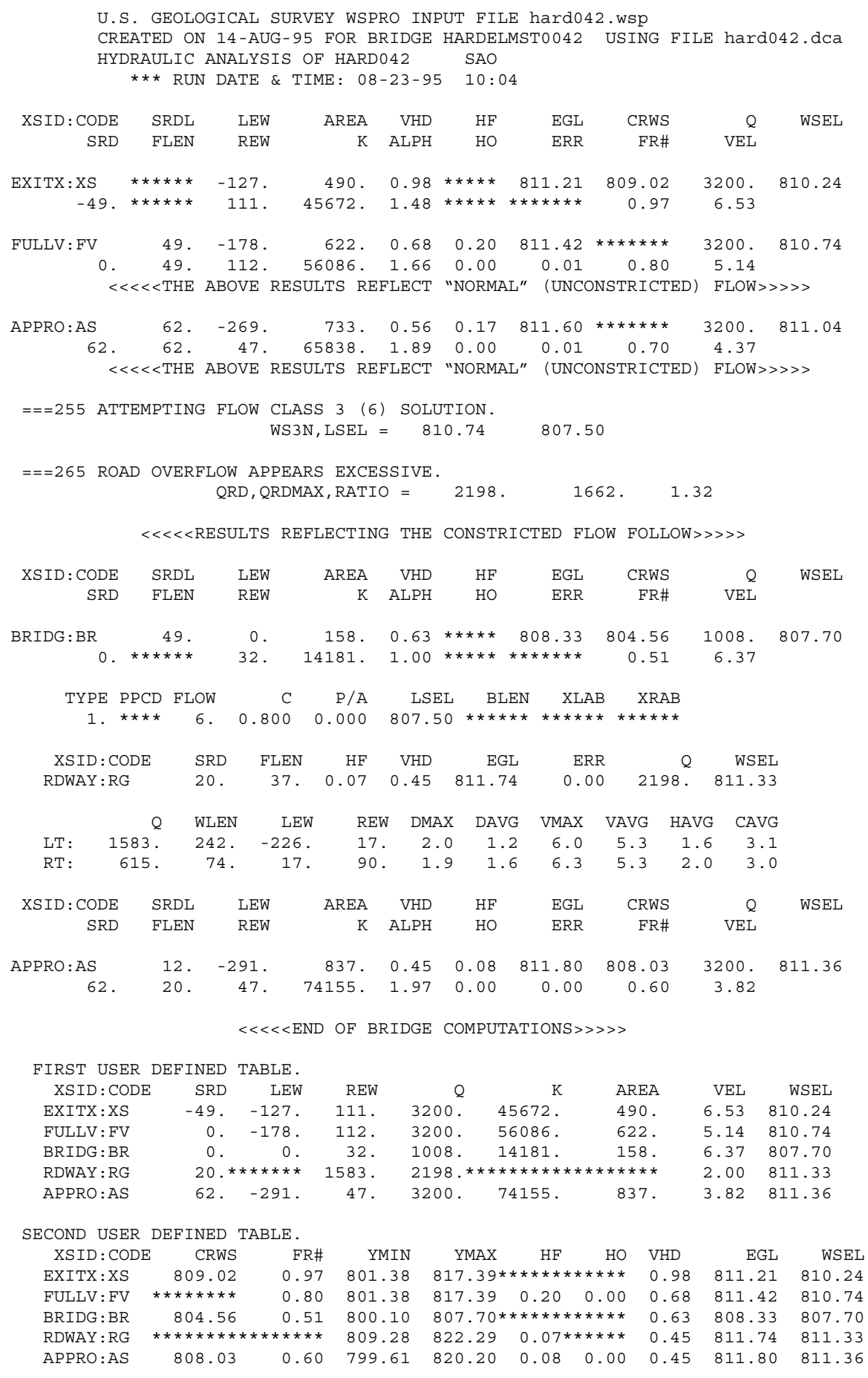


WSPRO OUTPUT FILE (continued)

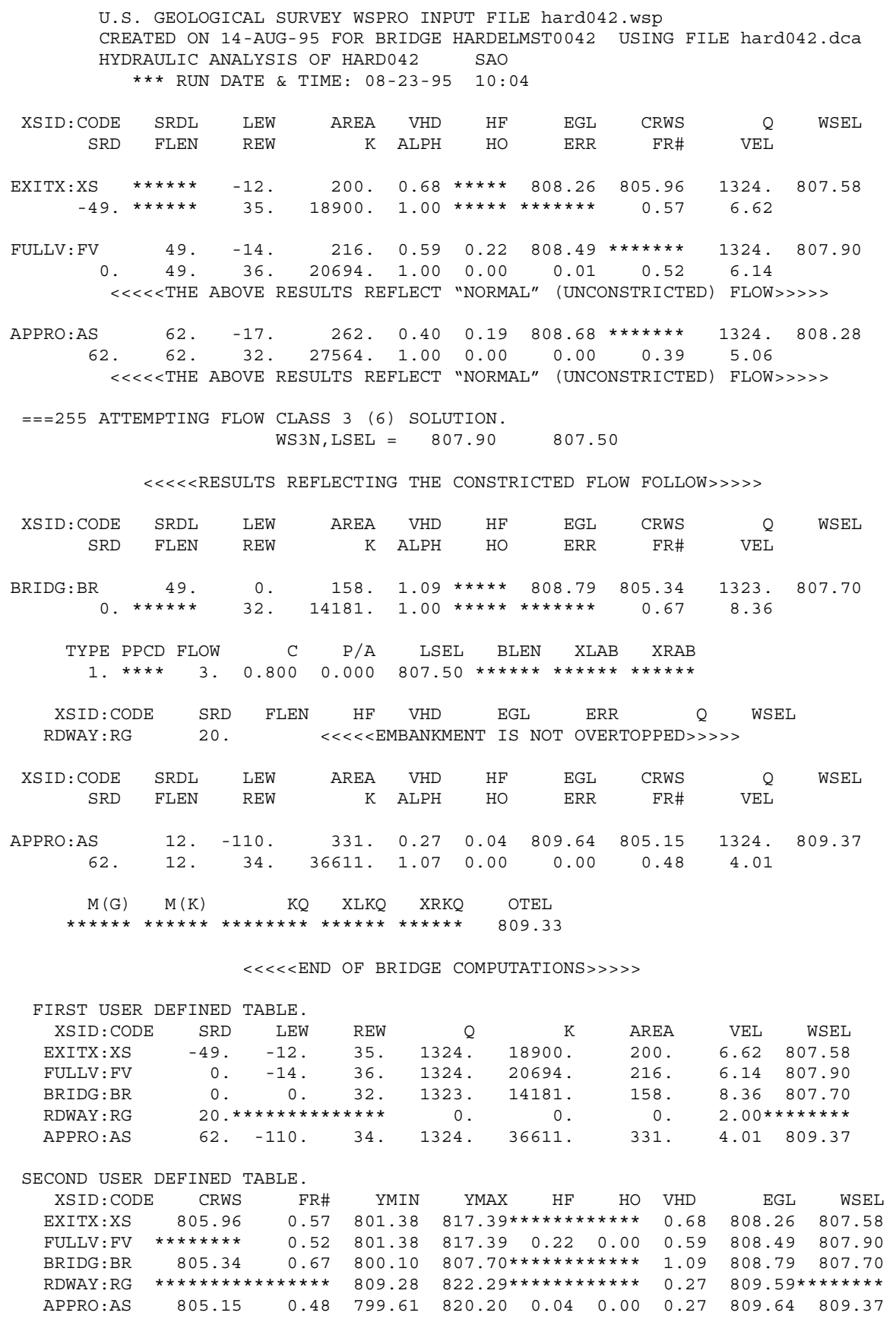




\section{APPENDIX C:}

\section{BED-MATERIAL PARTICAL-SIZE DISTRIBUTION}




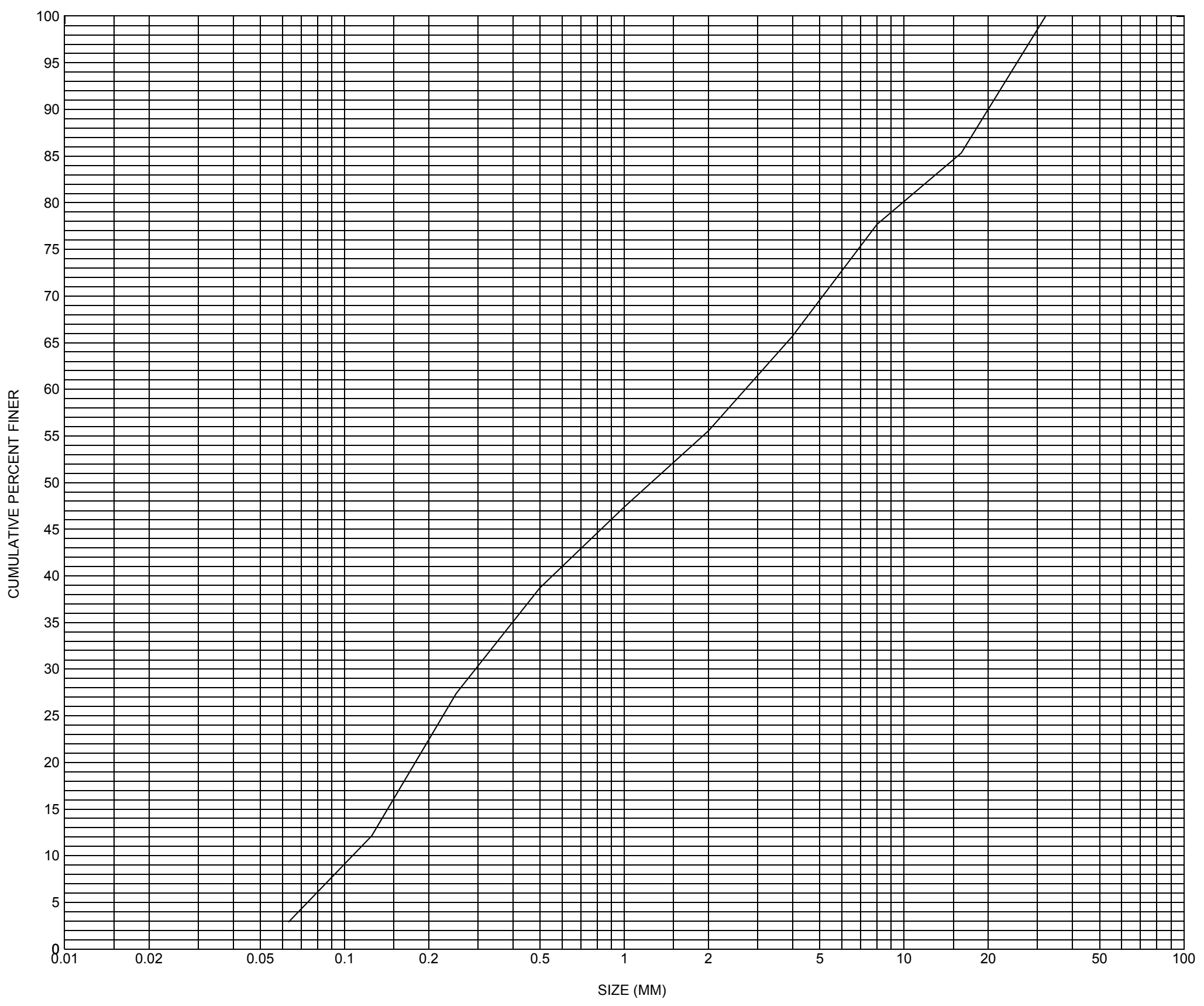

Appendix C. Bed material particle-size distribution for bed sample taken from the channel approach of structure HARDELMSTR0042, in Hardwick, Vermont. 


\section{APPENDIX D: \\ HISTORICAL DATA FORM}




\section{Structure Number HARDELMSTR0042}

\section{General Location Descriptive}

Data collected by (First Initial, Full last name) $\mathbf{E}$. BOEHMLER

Date $(M M / D D / Y Y) \_\mathbf{0 3} / \underline{17} / \underline{95}$

Highway District Number (I - 2; nn) $\mathbf{0 7}$

Town (FIPS place code; I - 4; nnnnn) $\mathbf{3 1 7 5 0}$

Waterway (I - 6) COOPER BROOK

Route Number -

Topographic Map Caspian.Lake

Latitude (I - 16; nnnn.n) $\mathbf{4 4 3 0 2}$
County (FIPS county code; I - 3; nnn)

Mile marker (I - 11; nnn.nnn) $\mathbf{0 0 0 0 0 0}$

Road Name (I - 7): ELM STREET

Vicinity (I - 9) ON ELM ST 0.2 MI W VT 15

Hydrologic Unit Code: $\mathbf{0 2 0 1 0 0 0 5}$

Longitude (i - 17; nnnnn.n) $\mathbf{7 2 2 2 6}$

\section{Select Federal Inventory Codes}

FHWA Structure Number (I - 8) $\mathbf{1 0 0 3 0 5 0 0 4 2 0 3 0 5}$

Maintenance responsibility $(I-21 ; n n) \_$03 $\quad$ Maximum span length $(I-48 ; n n n n) \underline{\mathbf{0 0 3 7}}$

Year built (I - 27; YYYY) 1985

Structure length (I - 49; nnnnnn) $\underline{\mathbf{0 0 0 0 3 9}}$

Average daily traffic, ADT (I - 29; nnnnnn) 000075 Deck Width (I - 52; nn.n) 254

Year of ADT (I - 30; YY) $\mathbf{9 3}$

Channel \& Protection $(I-61 ; n) \underline{7}$

Opening skew to Roadway $(I-34 ; n n) \quad \mathbf{4 8}$

Waterway adequacy $(I-71 ; n)$

Operational status $(I-41 ; X)$ A

Underwater Inspection Frequency $(I-92 B ; X Y Y) \_\mathbf{N}$

Structure type (I - 43; nnn) 101

Year Reconstructed (I - 106) $\mathbf{0 0 0 0}$

Approach span structure type $(I-44 ; n n n) \quad \mathbf{0 0 0}$

Clear span (nnn.n ft) $\quad \mathbf{0 2 5 . 0}$

Number of spans (I - 45; nnn) $\mathbf{0 0 1}$

Vertical clearance from streambed (nnn.n ft) $\underline{\mathbf{0 0 6} .7}$

Number of approach spans $(I-46 ; n n n n) \underline{\mathbf{0 0 0 0}}$ Waterway of full opening $\left(n n n . n f^{2}\right) \underline{\mathbf{1 7 5 . 0}}$

Comments:

The structural inspection report of 5/21/93 indicates the structure is a concrete slab type bridge. The deck is curved. The abutment walls and wingwalls are concrete. The right abutment reportedly has two fine vertical cracks and small leaks. Similarly the left abutment has three fine vertical cracks noted. The report also indicates that there is stone fill protection placed around the ends of the wingwalls and at least partially along the banks. Much of the visible stone fill, originally placed in front of the left abutment, was used to build a small "homemade" dam across the channel just downstream of the bridge. 


\section{Bridge Hydrologic Data}

Is there hydrologic data available? $\underline{\mathbf{Y}}$ if No, type ctrl-n $h \quad$ VTAOT Drainage area $\left(\mathrm{mi}^{2}\right)^{2}: \underline{\mathbf{1 6 . 4}}$ Terrain character: Hilly

Stream character \& type: Straight and a tributary to the Lamoille River.

Streambed material: Sandy to sandy gravel

Discharge Data (cfs): $\quad Q_{2.33} 725$

$\mathrm{Q}_{50} \mathbf{1 9 0 0}$

$\mathrm{Q}_{10} \frac{\mathbf{1 2 0 0}}{\mathbf{2 3 0 0}}$

$Q_{25} \frac{1500}{Q_{500}-}$

Record flood date (MM / DD / YY):

Estimated Discharge (cfs): I

Water surface elevation $(f t):-$

Ice conditions (Heavy, Moderate, Light): Moderate Debris (Heavy, Moderate, Light): Mod. to Heavy

The stage increases to maximum highwater elevation (Rapidly, Not rapidly): Rapidly

The stream response is (Flashy, Not flashy): Flashy

Describe any significant site conditions upstream or downstream that may influence the stream's stage: The stage of the river at this site is influenced during high frequency floods and ice jamming due to the Lamoille river about 0.5 miles downstream.

Watershed storage area (in percent): $\underline{5} \%$

The watershed storage area is: 1 (1-mainly at the headwaters; 2- uniformly distributed; 3-immediatly upstream oi the site)

Water Surface Elevation Estimates for Existing Structure:

\begin{tabular}{|l|l|l|l|l|l|}
\hline Peak discharge frequency & $Q_{2.33}$ & $Q_{10}$ & $Q_{25}$ & $Q_{50}$ & $Q_{100}$ \\
Water surface elevation $(f t))$ & $\mathbf{8 0 6 . 6}$ & $\mathbf{8 0 8 . 5}$ & $\mathbf{8 0 9 . 6}$ & $\mathbf{8 1 1 . 2}$ & $\mathbf{8 1 1 . 9}$ \\
Velocity $(f t / s e c)$ & $\mathbf{5 . 7}$ & $\mathbf{6 . 7}$ & $\mathbf{8 . 6}$ & $\mathbf{1 0 . 9}$ & $\mathbf{1 3 . 1}$ \\
\hline
\end{tabular}

Long term stream bed changes: Estimated scour depths are expected to be between 1 and 3 feet.

Is the roadway overtopped below the $Q_{100}$ ? (Yes, No, Unknown): $\mathbf{Y} \quad$ Frequency: $\underline{\mathbf{Q} 45}$ Relief Elevation $(f t): \underline{\text { 811.0 }}$ Discharge over roadway at $\mathrm{Q}_{100}\left(f^{3} / \mathrm{sec}\right): \underline{\mathbf{4 7 5 . 0}}$

Are there other structures nearby? (Yes, No, Unknown): $\mathbf{Y}$ If No or Unknown, type ctrl-n os Upstream distance (miles): $\mathbf{0 . 5}$ Town: Hardwick Highway No. : VT14 Structure No. : 92\&93 Structure Type:

Clear span $(f t): \underline{\mathbf{7 . 0}}$ Clear Height $(f t): \underline{\mathbf{7 . 0}}$ Full Waterway $\left(f t^{2}\right): \underline{49.0}$ 
Downstream distance (miles): 0.5 Town: Hardwick Year Built:

Highway No. : VT15 Structure No. : 67 Structure Type:

Clear span (ft): $\underline{\mathbf{5 9 . 0}}$ Clear Height $(f t): \underline{\mathbf{6 . 0}}$ Full Waterway $\left(f t^{2}\right):$

Comments:

The stone fill class recommended for bank protection at this site is type II.

\section{USGS Watershed Data}

Watershed Hydrographic Data

Drainage area $(D A) \underline{16.56} \mathrm{mi}^{2}$

Watershed storage (ST) $\quad \mathbf{4 . 7 8}$

Bridge site elevation $\mathbf{8 2 0} \mathrm{ft}$ $\%$

Main channel length $\mathbf{7 . 4 9 5} \mathrm{mi}$

$10 \%$ channel length elevation $\mathbf{8 2 4}$ $\mathrm{ft} \quad 85 \%$ channel length elevation $\mathrm{ft}$

Main channel slope $(S) \quad \mathbf{1 0 6 . 2} \mathrm{ft} / \mathrm{mi}$

Watershed Precipitation Data

Average site precipitation in Average headwater precipitation in

Maximum 2yr-24hr precipitation event $(124,2)$ in

Average seasonal snowfall (Sn) $\mathrm{ft}$ 


\section{Bridge Plan Data}

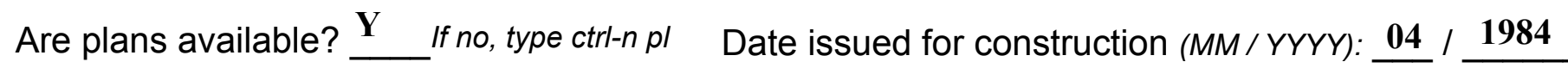
Project Number BRZ1447(3)

Minimum channel bed elevation: $\mathbf{8 0 3 . 0}$

Low superstructure elevation: USLAB $\underline{\mathbf{8 0 9 . 0 4}}$ DSLAB $\underline{\mathbf{8 0 8 . 6 2}}$ USRAB $\underline{\mathbf{8 0 9 . 2 6}}$ DSRAB $\underline{\mathbf{8 0 8 . 8 7}}$ Benchmark location description:

Bronze disk [center of engraved triangle] on top of the concrete near the corner of the downstream right wingwall where it meets the right abutment, elevation 811.57.

Reference Point (MSL, Arbitrary, Other): MSL Datum (NAD27, NAD83, Other): NAD1929

Foundation Type: 1 (1-Spreadfooting; 2-Pile; 3- Gravity; 4-Unknown)

If 1: Footing Thickness $\mathbf{2 . 0} \quad$ Footing bottom elevation: $\underline{\mathbf{7 9 8 . 0}}$

If 2: Pile Type:___ (1-Wood; 2-Steel or metal; 3-Concrete) Approximate pile driven length:

If 3: Footing bottom elevation:

Is boring information available? $\underline{\mathbf{Y}}$ If no, type ctrl- $n$ bi Number of borings taken: $\underline{\mathbf{2}}$

Foundation Material Type: 1 (1-regolith, 2-bedrock, 3-unknown)

Briefly describe material at foundation bottom elevation or around piles:

The footings are set in a wet, brown, sandy gravel.

Comments:

Other points displayed on the plans with elevations are: 1) The point on the top streamward edge of the concrete upstream left wingwall where the concrete meets the left abutment, elevation 811.70, and 2) the point at the top streamward edge of the concrete upstream right wingwall where the concrete slope changes from horizontal to downward, elevation 812.00. 


\section{Cross-sectional Data}

Is cross-sectional data available? $\underline{\mathbf{Y}}$ If no, type ctrl-n xs

Source (FEMA, VTAOT, Other)? VTAOT

Comments: Orientation of the cross sections is inconsistent with any cross section data surveyed for this study and is not comparable. Data was not retrieved.

\begin{tabular}{|l|l|l|l|l|l|l|l|l|l|l|l|}
\hline Station & & & & & & & & & & & \\
\hline Feature & & & & & & & & & & & \\
\hline $\begin{array}{l}\text { Low cord } \\
\text { elevation }\end{array}$ & & & & & & & & & & & \\
\hline $\begin{array}{l}\text { Bed } \\
\text { elevation }\end{array}$ & & & & & & & & & & & \\
\hline $\begin{array}{l}\text { Low cord to } \\
\text { bed length }\end{array}$ & & & & & & & & & & & \\
\hline Station & & & & & & & & & & & \\
\hline Feature & & & & & & & & & & & \\
\hline $\begin{array}{l}\text { Low cord } \\
\text { elevation }\end{array}$ & & & & & & & & & & & \\
\hline $\begin{array}{l}\text { Bed } \\
\text { elevation }\end{array}$ & & & & & & & & & & & \\
\hline $\begin{array}{l}\text { Low cord to } \\
\text { bed length }\end{array}$ & & & & & & & & & & & \\
\hline
\end{tabular}

Source (FEMA, VTAOT, Other)?

Comments:

\begin{tabular}{|l|l|l|l|l|l|l|l|l|l|l|l|}
\hline Station & & & & & & & & & & & \\
\hline Feature & & & & & & & & & & & \\
\hline $\begin{array}{l}\text { Low cord } \\
\text { elevation }\end{array}$ & & & & & & & & & & & \\
\hline $\begin{array}{l}\text { Bed } \\
\text { elevation }\end{array}$ & & & & & & & & & & & \\
\hline $\begin{array}{l}\text { Low cord to } \\
\text { bed length }\end{array}$ & & & & & & & & & & & \\
\hline Station & & & & & & & & & & & \\
\hline Feature & & & & & & & & & & & \\
\hline $\begin{array}{l}\text { Low cord } \\
\text { elevation }\end{array}$ & & & & & & & & & & & \\
\hline $\begin{array}{l}\text { Bed } \\
\text { elevation }\end{array}$ & & & & & & & & & & & \\
\hline $\begin{array}{l}\text { Low cord to } \\
\text { bed length }\end{array}$ & & & & & & & & & & & \\
\hline
\end{tabular}




\section{APPENDIX E: \\ LEVEL I DATA FORM}


U. S. Geological Survey

Bridge Field Data Collection and Processing Form

Qa/Qc Check by: MAI Date: $09 / 13 / 95$

sin

\section{A. General Location Descriptive}

1. Data collected by (First Initial, Full last name) $\mathbf{R}$. Hammond

2. Highway District Number 7

Mile marker $\mathbf{0}$

County Caledonia (005)

Town Hardwick (31750)

Waterway (I - 6) Cooper Brook

Road Name EIm Street

Route Number -

Hydrologic Unit Code: 02010005

3. Descriptive comments:

On Elm Street 0.2 miles west of VT 15.

Site revisited on 08/17/95 by $\mathbf{J}$. Ayotte after high water flows. Comments made during the revisit are in italics.

\section{B. Bridge Deck Observations}
4. Surface cover... LBUS 2
RBUS 6
LBDS 2
RBDS 2
Overall 2

(2b us, ds,lb,rb: 1- Urban; 2- Suburban; 3- Row crops; 4- Pasture; 5- Shrub- and brushland; 6- Forest; 7- Wetland)
5. Ambient water surface... US 1
UB 1
DS 1
(1- pool; 2- riffle)

6. Bridge structure type 1 (1- single span; 2- multiple span; 3- single arch; 4- multiple arch; 5-cylindrical culvert; 6- box culvert; or 7- other)
7. Bridge length $\mathbf{3 9 . 0}$
(feet)
Span length $\mathbf{3 7 . 0}$
(feet)
Bridge width 25.4 (feet)

\section{Road approach to bridge:}
8. LB 2
RB 2
( 0 even, 1- lower, 2- higher)
9. LB_
RB $\underline{2}$
(1-Paved, 2- Not paved)

10. Embankment slope (run / rise in feet / foot)

US left --:1

US right $\quad 2.5: 1$

\begin{tabular}{|c|c|c|c|c|}
\hline & \multicolumn{2}{|c|}{ Protection } & \multirow{2}{*}{ 13. Erosion } & \multirow{2}{*}{ 14.Severity } \\
\hline & 11.Type & 12.Cond. & & \\
\hline LBUS & 0 & - & $\mathbf{0}$ & - \\
\hline RBUS & $\mathbf{0}$ & - & 2 & 2 \\
\hline RBDS & $\mathbf{0}$ & - & $\mathbf{0}$ & - \\
\hline LBDS & $\mathbf{0}$ & - & 2 & 2 \\
\hline
\end{tabular}

Bank protection types: 0- none; 1- < 12 inches;

2- $<36$ inches; $3-<48$ inches;

4- < 60 inches; 5- wall / artificial levee

Bank protection conditions: 1- good; 2- slumped;

3- eroded; 4- failed

Erosion: 0 - none; 1- channel erosion; 2 -

road wash; 3- both; 4- other

Erosion Severity: 0 - none; 1- slight; 2- moderate; 3- severe

\section{Channel approach to bridge (BF):}

15. Angle of approach: $\underline{\mathbf{2 0}}$

16. Bridge skew: $\mathbf{4 0}$

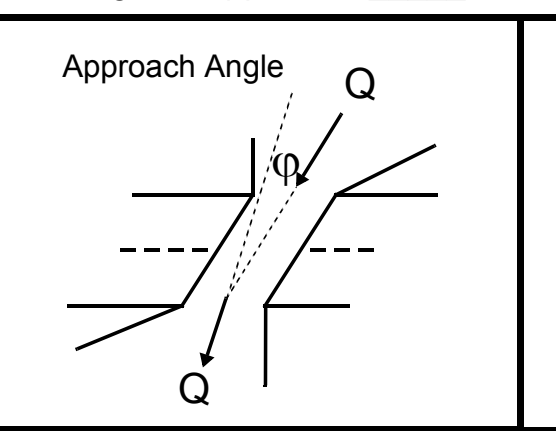

17. Channel impact zone 1:

Where? RB (LB, RB)

Exist? $\mathbf{Y}$ (Y or $N)$ Bridge Skew Angle

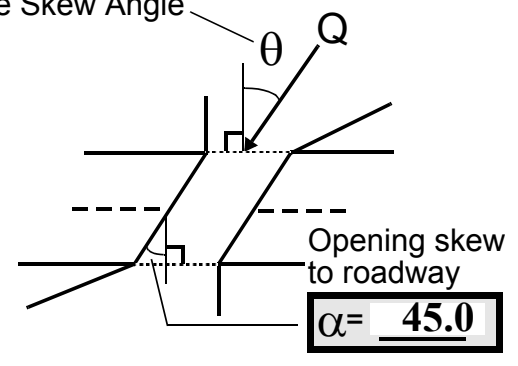

Range? 15 feet US

Severity 2

Channel impact zone 2:

(US, UB, DS) to 0 feet US

Where? (LB, RB)

Exist? $(Y$ or $N)$

Range? feet (US, UB, DS) to feet Impact Severity: 0- none to very slight; 1- Slight; 2- Moderate; 3- Severe 
18. Bridge Type: 1 a \& 4

1a- Vertical abutments with wingwalls

1 b- Vertical abutments without wingwalls

2- Vertical abutments and wingwalls, sloping embankment Wingwalls perpendicular to abut. face

3- Spill through abutments

4- Sloping embankment, vertical wingwalls and abutments

Wingwall angle less than $90^{\circ}$.
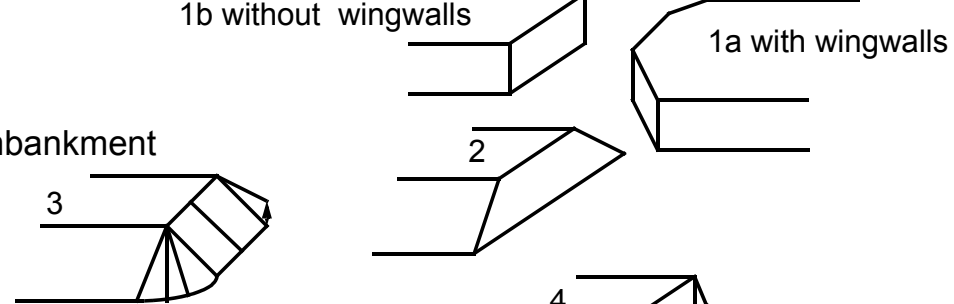

19. Bridge Deck Comments (surface cover variations, measured bridge and span lengths, bridge type variations, approach overflow width, etc.)

4. Left bank upstream is used to store lumber and is relatively flat. There are logs and cut lumber.

7. Measured length upstream 36.7 and downstream 39.7, span upstream 32.3 and downstream 34.6, and width 25.4 feet.

8. Road is slightly higher than the bridge deck.

18. Upstream bridge face right wingwall is type 4 and left is type 1a. The downstream bridge face right wingwall is type 1a and left is type 4.

\section{Upstream Channel Assessment}

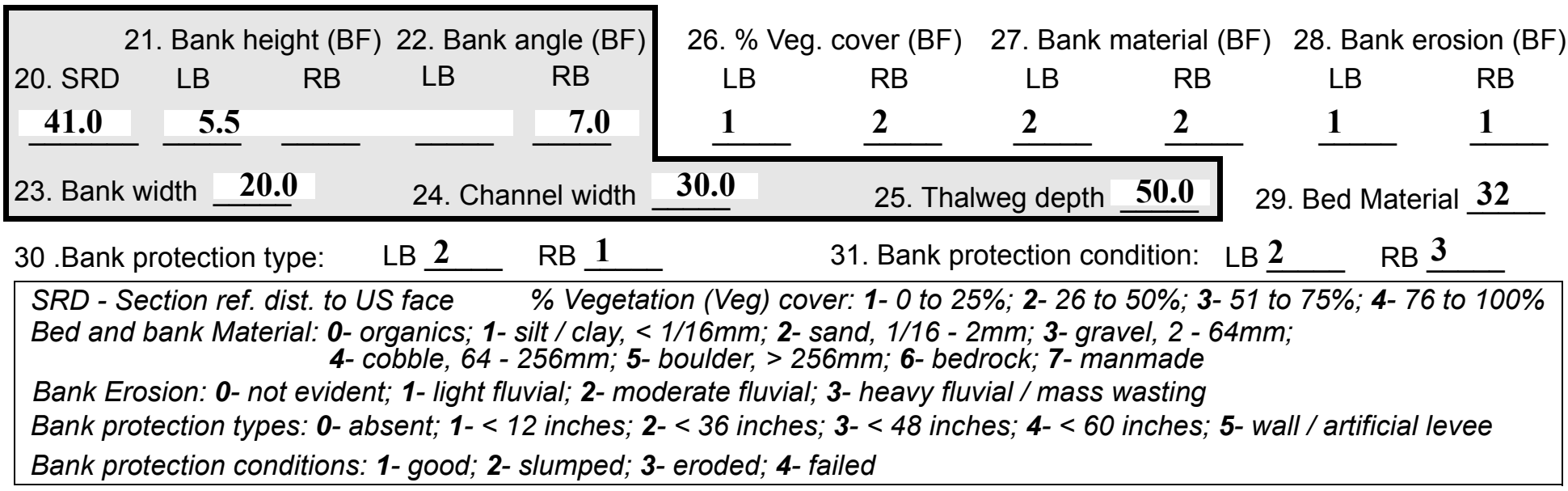

32. Comments (bank material variation, minor inflows, protection extent, etc.):

27. Bank material consist of sand.

28. Bed material consist of gravel and sand.

30. Left bank protection extent is 57 to 64 feet upstream.

Right bank protection extent is along the base of the wingwall to 23 feet upstream. The protection is sparse. 
33.Point/Side bar present? Y

$(Y$ or $N$. if $N$ type ctrl-n pb) 34 . Mid-bar distance: $\mathbf{0}$

35. Mid-bar width: 6

36. Point bar extent: $\mathbf{5 0}$ feet $\mathbf{U S}$

(US, UB) to $\mathbf{5 5}$ feet $\underline{\mathbf{D S}}$

(US, UB, DS) positioned $\mathbf{0}$

\%LB to $\mathbf{2 0}$ $\% \mathrm{RB}$

37. Material: $\mathbf{2 3}$

38. Point or side bar comments (Circle Point or Side; Note additional bars, material variation, status, etc.):

On 8/17/95, the point bar dimensions had changed to $10 \mathrm{ft}$ US to $56 \mathrm{ft}$ US. The mid-bar distance was $45 \mathrm{ft} U S$ and the mid-bar width was $7 \mathrm{ft}$.

39. Is a cut-bank present? $\mathbf{Y}$ (Y or if $N$ type ctrl-n cb)

40. Where? $\underline{\text { LB }}$ (LB or RB)

41. Mid-bank distance: $\mathbf{8 0}$

42. Cut bank extent: 90 feet $\underline{\text { US }}$ (US, UB, DS)

43. Bank damage: 3

(1- eroded and/or creep; 2- slip failure; 3- block failure)

44. Cut bank comments (eg. additional cut banks, protection condition, etc.):

Roots are undercut and exposed. The cut is unusual in that it is on the inside of the bend.

On 8/17/95: Block failure with small trees fallen into the channel.

\section{Is channel scour present? $\mathbf{Y}$ ( $Y$ or if $N$ type ctrl-n cs) 46. Mid-scour distance: 10 US}
47. Scour dimensions: Length $\mathbf{1 0}$
Width 3
Depth : 1
Position $\underline{60} \%$ LB to $\underline{75} \%$ RB

48. Scour comments (eg. additional scour areas, local scouring process, etc.):

Small scour hole with a firm base.

On 08/17/95 the scour hole positioned $50 \% \mathrm{LB}$ to $95 \% \mathrm{RB}$, from 0 to 58 feet upstream with a mid-scour distance at 20 feet US. Scour depth is 1.5 feet.

49. Are there major confluences? $\mathbf{N}$

51. Confluence 1: Distance -

Confluence 2: Distance -

54. Confluence comments (eg. confluence name):

NO MAJOR CONFLUENCES
(Y or if $N$ type ctrl-n mc)

52. Enters on -

Enters on (LB or $R B)$ $(L B$ or $R B)$
50. How many? -

53. Type(1-perennial; 2- ephemeral)

Type (1- perennial; 2- ephemeral)

\section{Under Bridge Channel Assessment}

55. Channel restraint (BF)? LB 2

\begin{tabular}{|ccccc}
\hline \multicolumn{2}{|c}{56. Height (BF) } & \multicolumn{3}{c}{57 Angle (BF) } \\
LB & RB & LB & RB \\
$\mathbf{2 3 . 0}$ & & & $\mathbf{2 . 0}$ & \\
\hline
\end{tabular}

(1- natural bank; 2- abutment; 3- artificial levee)

\begin{tabular}{llll} 
61. Material (BF) & \multicolumn{3}{l}{ 62. Erosion (BF) } \\
LB & RB & LB & RB \\
$\mathbf{2}$ & $\mathbf{7}$ & $\underline{7}$ & $\mathbf{0}$ \\
\hline
\end{tabular}

60. Thalweg depth (Amb) $\mathbf{9 0 . 0}$

63. Bed Material $\mathbf{0}$

58. Bank width (BF) -

59. Channel width (Amb) -

Bed and bank Material: 0- organics; 1- silt / clay, < 1/16mm; 2- sand, 1/16 - 2mm; 3- gravel, 2 - 64mm; 4- cobble, 64 - 256mm; 5- boulder, > 256mm; 6- bedrock; 7- manmade

Bank Erosion: 0- not evident; 1- light fluvial; 2- moderate fluvial; 3- heavy fluvial / mass wasting

64. Comments (bank material variation, minor inflows, protection extent, etc.):

321

63. Bed material consist of gravel, sand, and some silt/clay.

On 8/17/95: A scour hole exists under the middle of the bridge from the upstream to the downstream face, posi-

tioned $15 \% \mathrm{LB}$ to $100 \% \mathrm{RB}$, with a scour depth of 2 feet.

On 8/17/95: The under bridge portion of the left bank point bar has been removed from flows. 
65. Debris and Ice Is there debris accumulation?

$(Y$ or $N)$ 66. Where? $\underline{Y}$

(1- Upstream; 2- At bridge; 3- Both)

67. Debris Potential 1 (1-Low; 2- Moderate; 3- High)

68. Capture Efficiency 2

(1-Low; 2- Moderate; 3- High)

69. Is there evidence of ice build-up? 1 ( $Y$ or $N)$

Ice Blockage Potential Y

(1-Low; 2- Moderate; 3- High)

70. Debris and Ice Comments:

1

69. Hydraulic report indicated moderate ice conditions.

\begin{tabular}{|l|c|c|c|c|c|c|c|c|}
\hline Abutments & $\begin{array}{c}\text { 71. Attack } \\
\angle \mathrm{BF})\end{array}$ & $\begin{array}{c}\text { 72. Slope } \\
(\mathrm{Qmax})\end{array}$ & $\begin{array}{l}\text { 73. Toe } \\
\text { loc. (BF) }\end{array}$ & $\begin{array}{c}\text { 74. Scour } \\
\text { Condition }\end{array}$ & $\begin{array}{c}\text { 75. Scour } \\
\text { depth }\end{array}$ & $\begin{array}{c}\text { 76. Exposure } \\
\text { depth }\end{array}$ & 77. Material & 78. Length \\
\hline LABUT & & - & $\mathbf{9 0}$ & $\mathbf{2}$ & $\mathbf{0}$ & - & $\mathbf{0}$ & $\mathbf{9 0 . 0}$ \\
\hline RABUT & $\mathbf{1}$ & $\mathbf{2 0}$ & $\mathbf{9 0}$ & & & $\mathbf{2}$ & $\mathbf{1}$ & $\mathbf{2 3 . 0}$ \\
\hline
\end{tabular}

Pushed: $L B$ or RB

Toe Location (Loc.): 0- even, 1- set back, 2- protrudes

Scour cond.: 0- not evident; 1- evident (comment); 2- footing exposed; 3-undermined footing; 4- piling exposed; 5- settled; 6- failed

Materials: 1- Concrete; 2- Stone masonry or drywall; 3- steel or metal; 4- wood

79. Abutment comments (eg. undermined penetration, unusual scour processes, debris, etc.):

.5

0

1

75. The deepest part of channel under the bridge is along the right abutment. Footings not exposed.

On 8/17/95: the deepest point is at the center of the channel under the bridge.

80. Wingwalls:

Exist? Material? Scour Scour Exposure $\begin{array}{ll}81 . & \\ \text { Angle? Length? }\end{array}$ Condition? depth? depth?

USLWW:

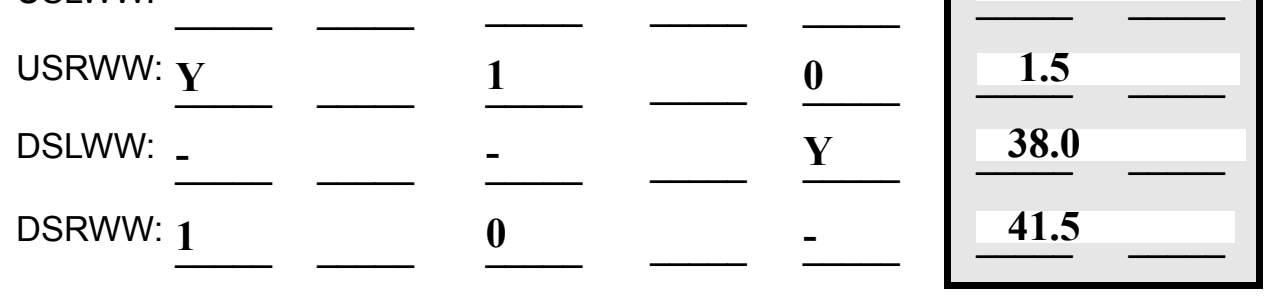

Wingwall materials: 1- Concrete; 2- Stone masonry or drywall; 3- steel or metal; 4- wood

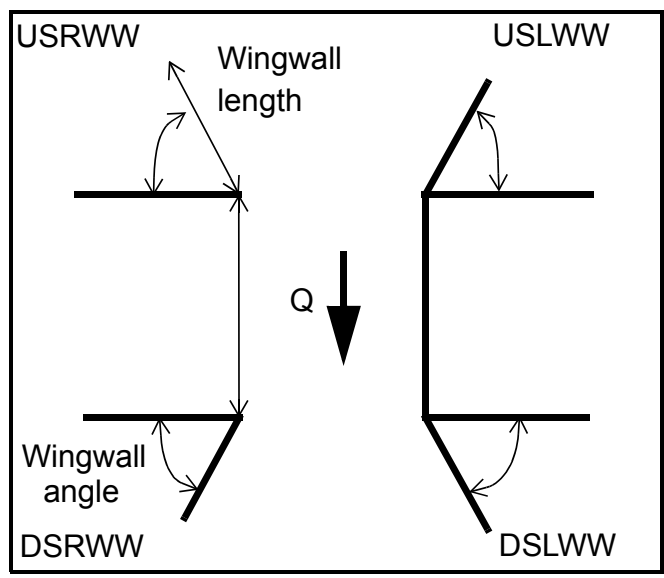

82. Bank / Bridge Protection:

\begin{tabular}{|l|l|l|l|l|l|l|l|l|}
\hline Location & USLWW & USRWW & LABUT & RABUT & LB & RB & DSLWW & DSRWW \\
\hline Type & - & $\mathbf{0}$ & $\mathbf{Y}$ & - & $\mathbf{1}$ & $\mathbf{1}$ & - & $\mathbf{1}$ \\
\hline Condition & $\mathbf{Y}$ & - & $\mathbf{1}$ & - & $\mathbf{1}$ & $\mathbf{1}$ & - & $\mathbf{1}$ \\
\hline Extent & $\mathbf{1}$ & - & $\mathbf{0}$ & $\mathbf{2}$ & $\mathbf{2}$ & $\mathbf{0 2}$ & $\mathbf{2}$ & - \\
\hline
\end{tabular}

Bank / Bridge protection types: 0- absent; 1- < 12 inches; 2- < 36 inches; 3- < 48 inches; 4- < 60 inches; 
83. Wingwall and protection comments (eg. undermined penetration, unusual scour processes, etc.):

-
-
-
-
-
0
-
-
2
1
1

\section{Piers:}

84. Are there piers? $\quad$ Pr $(Y$ or if $N$ type ctrl-n pr)

\begin{tabular}{|l|l|l|l|l|l|l|l|}
\hline \multirow{2}{*}{$\begin{array}{l}85 . \\
\text { Pier no. }\end{array}$} & \multicolumn{3}{|c|}{ width (w) feet } & \multicolumn{5}{c|}{ elevation (e) feet } \\
\cline { 2 - 8 } & w1 & w2 & w3 & e@w1 & e@w2 & e@w3 \\
\hline Pier 1 & & & & $\mathbf{1 0 . 0}$ & $\mathbf{1 9 . 0}$ & $\mathbf{1 0 5 . 0}$ \\
\hline Pier 2 & $\mathbf{1 1 . 5}$ & $\mathbf{9 . 0}$ & & $\mathbf{9 5 . 0}$ & $\mathbf{2 0 . 0}$ & $\mathbf{2 0 . 5}$ \\
\hline Pier 3 & - & - & - & - & - & - & w1 \\
\hline Pier 4 & - & - & - & - & - & - & w2 \\
\hline
\end{tabular}

\begin{tabular}{|c|c|c|c|c|}
\hline Level 1 Pier Descr. & 1 & 2 & 3 & 4 \\
\hline 86. Location (BF) & otec- & alon & fine & the \\
\hline 87. Type & tion & gleft & silt. & pro- \\
\hline 88. Material & is & abut- & Duri & tec- \\
\hline 89. Shape & spar & ment & $n g$ & tion \\
\hline 90. Inclined? & se. & exist & pre- & had \\
\hline 91. Attack $\angle(B F)$ & 82. & s and & vious & been \\
\hline 92. Pushed & On & is & level & com- \\
\hline 93. Length (feet) & - & - & - & - \\
\hline 94. \# of piles & $8 / 17 /$ & cov- & $I$ & pletel \\
\hline 95. Cross-members & 95: & ered & data & $y$ \\
\hline 96. Scour Condition & pro- & by $a$ & col- & cov- \\
\hline 97. Scour depth & tec- & layer & lec- & ered \\
\hline 98. Exposure depth & tion & $o f$ & tion, & by $a$ \\
\hline
\end{tabular}

LFP, LTB, LB, MCL, MCM, MCR, RB, RTB, RFP

1- Solid pier, 2- column, 3- bent

1-Wood; 2- concrete; 3- metal; 4- stone

1- Round; 2- Square; 3- Pointed

Y-yes; $N$ - no

$L B$ or $R B$

0- none; 1- laterals; 2- diagonals; 3- both

0- not evident; 1- evident (comment);

2- footing exposed; 3- piling exposed;

4- undermined footing; 5- settled; 6- failed 
99. Pier comments (eg. undermined penetration, protection and protection extent, unusual scour processes, etc.):

\section{point bar.}

$\mathbf{N}$

100.

\section{E. Downstream Channel Assessment}

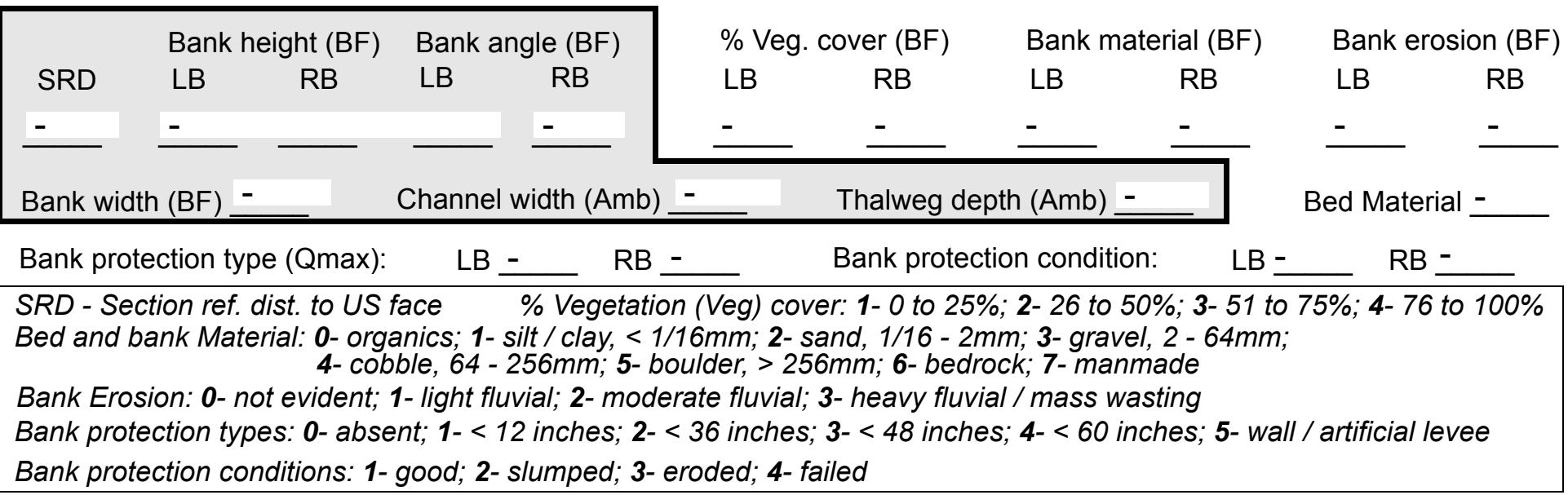

Comments (eg. bank material variation, minor inflows, protection extent, etc.):

,

\section{Is a drop structure present? _ ( $Y$ or $N$, if $N$ type ctrl-n ds) 102. Distance: _ _ feet}

103. Drop: -_ feet 104. Structure material: ___ (1- steel sheet pile; 2- wood pile; 3- concrete; 4- other)

105. Drop structure comments (eg. downstream scour depth): 
106. Point/Side bar present? (Y or $N$. if $N$ type ctrl-n pb)Mid-bar distance:

Mid-bar width: -

Point bar extent: feet -

(US, UB, DS) to feet (US, UB, DS) positioned \%LB to $\%$ RB Material:

Point or side bar comments (Circle Point or Side; note additional bars, material variation, status, etc.):

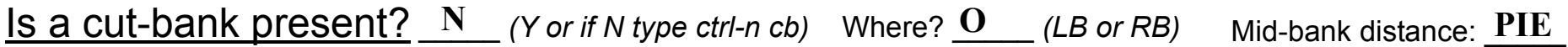
Cut bank extent: $\underline{\mathbf{R S}}$ feet __ (US, UB, DS) to feet ___ (US, UB, DS)

Bank damage: (1- eroded and/or creep; 2- slip failure; 3- block failure)

Cut bank comments (eg. additional cut banks, protection condition, etc.):

Is channel scour present? (Y or if $N$ type ctrl-n cs) Width 2 Depth: 2 Mid-scour distance: 1 Scour dimensions: Length 1

Scour comments (eg. additional scour areas, local scouring process, etc.): 231

$\mathbf{0}$

$\mathbf{0}$

Are there major confluences? ( $Y$ or if $N$ type ctrl-n $m c)$

Positioned 1 \%LB to 1 $\% \mathrm{RB}$ Confluence 1: Distance $\mathbf{k}$ Enters on mat (LB or RB) Enters on sists (LB or RB)

Confluence 2: Distance conConfluence comments (eg. confluence name):

sand.

Bed material consists of sand, gravel, and some silt/clay.
How many? Ban

Type erial (1- perennial; 2- ephemeral)

Type of (1-perennial; 2- ephemeral)

\section{F. Geomorphic Channel Assessment}

107. Stage of reach evolution
1- Constructed

2- Stable

3- Aggraded

4- Degraded

5- Laterally unstable

6- Vertically and laterally unstable 
108. Evolution comments (Channel evolution not considering bridge effects; See HEC-20, Figure 1 for geomorphic descriptors): 


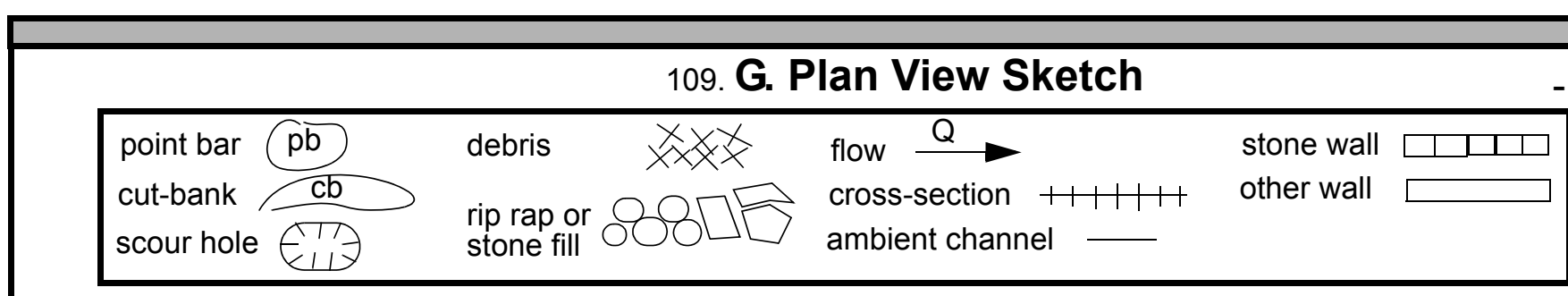


APPENDIX F:

SCOUR COMPUTATIONS 


\begin{tabular}{|c|c|c|c|}
\hline Structure Number: HARDELMST0042 & & Town: & HARDWICK \\
\hline Road Number: $\quad$ ELM STREET & & County: & CALEDONIA \\
\hline Stream: COOPER BROOK & & & \\
\hline Initials SAO & & Checked: & EMB \\
\hline Analysis of contraction scour, liv & -bed or $\mathrm{cl}$ & lear wat & $r ?$ \\
\hline eills Equation & & & \\
\hline $\mathrm{VC}=11.52 * \mathrm{Y} 1^{\wedge} 0.1667 * \mathrm{D} 50^{\wedge} 0.33$ with $\mathrm{S}$ & $=2.65$ & & \\
\hline Approach Section & & & \\
\hline Characteristic & $100 \mathrm{yr}$ & 500 yr & other Q \\
\hline Total discharge, cfs & 2300 & 3200 & 1324 \\
\hline Main Channel Area, ft2 & 397 & 426 & 319 \\
\hline Left overbank area, ft2 & 260 & 397 & 11 \\
\hline Right overbank area, ft2 & 9 & 15 & 0 \\
\hline Top width main channel, ft & 54 & 54 & 54 \\
\hline Top width L overbank, ft & 234 & 272 & 90 \\
\hline Top width $\mathrm{R}$ overbank, ft & 12 & 13 & 0 \\
\hline D50 of channel, ft & 0.00409 & 0.00409 & 0.00409 \\
\hline D50 left overbank, ft & 0 & 0 & 0 \\
\hline D50 right overbank, ft & 0 & 0 & 0 \\
\hline Y1, average depth, MC, ft & 7.4 & 7.9 & 5.9 \\
\hline y1, average depth, LOB, ft & 1.1 & 1.5 & 0.1 \\
\hline Y1, average depth, ROB, ft & 0.8 & 1.2 & 0.0 \\
\hline Total conveyance, approach & 60651 & 74246 & 36565 \\
\hline Conveyance, main channel & 52323 & 58885 & 36482 \\
\hline Conveyance, LOB & 8148 & 14900 & 82 \\
\hline Conveyance, ROB & 180 & 460 & 0 \\
\hline Percent discrepancy, conveyance & 0 & 0.001347 & 0.002735 \\
\hline Qm, discharge, MC, cfs & 1984.187 & 2537.941 & 1320.995 \\
\hline Q1, discharge, LOB, cfs & 308.9875 & 642.1895 & 2.969178 \\
\hline Qr, discharge, ROB, cfs & 6.825939 & 19.82598 & 0 \\
\hline Vm, mean velocity $\mathrm{MC}$, ft/s & 5.0 & 6.0 & 4.1 \\
\hline Vl, mean velocity, LOB, ft/s & 1.2 & 1.6 & 0.3 \\
\hline Vr, mean velocity, ROB, ft/s & 0.8 & 1.3 & 0.0 \\
\hline Vc-m, crit. velocity, MC, ft/s & 2.6 & 2.6 & 2.5 \\
\hline Vc-l, crit. velocity, LOB, ft/s & 0.0 & 0.0 & 0.0 \\
\hline Vc-r, crit. velocity, ROB, ft/s & 0.0 & 0.0 & 0.0 \\
\hline Results & & & \\
\hline Live-bed(1) or Clear-Water(0) Cont & action Scc & our? & \\
\hline Main Channel & 1 & 1 & 1 \\
\hline Left Overbank & $\mathrm{N} / \mathrm{A}$ & $\mathrm{N} / \mathrm{A}$ & $\mathrm{N} / \mathrm{A}$ \\
\hline Right Overbank & $\mathrm{N} / \mathrm{A}$ & $\mathrm{N} / \mathrm{A}$ & $\mathrm{N} / \mathrm{A}$ \\
\hline
\end{tabular}




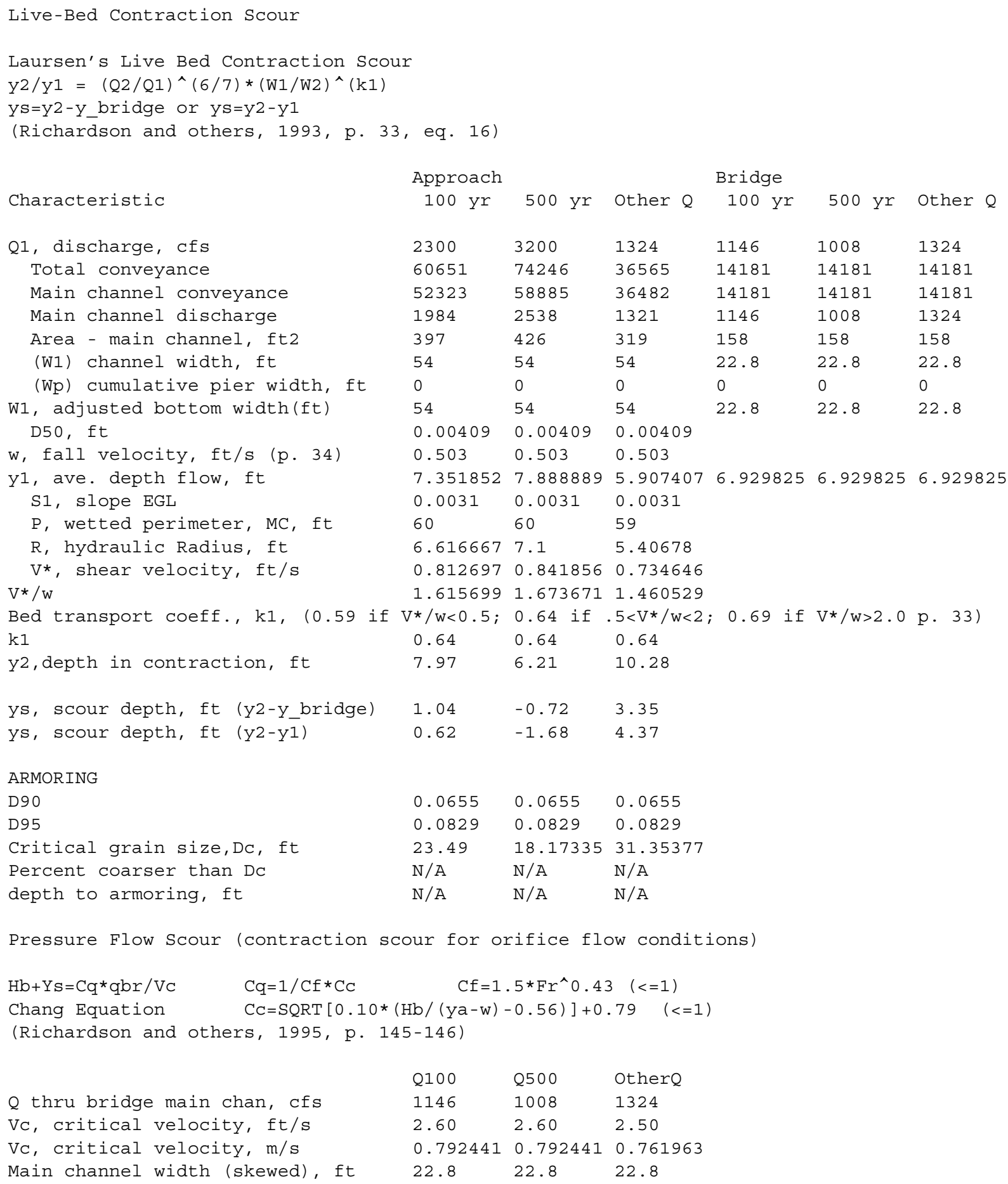




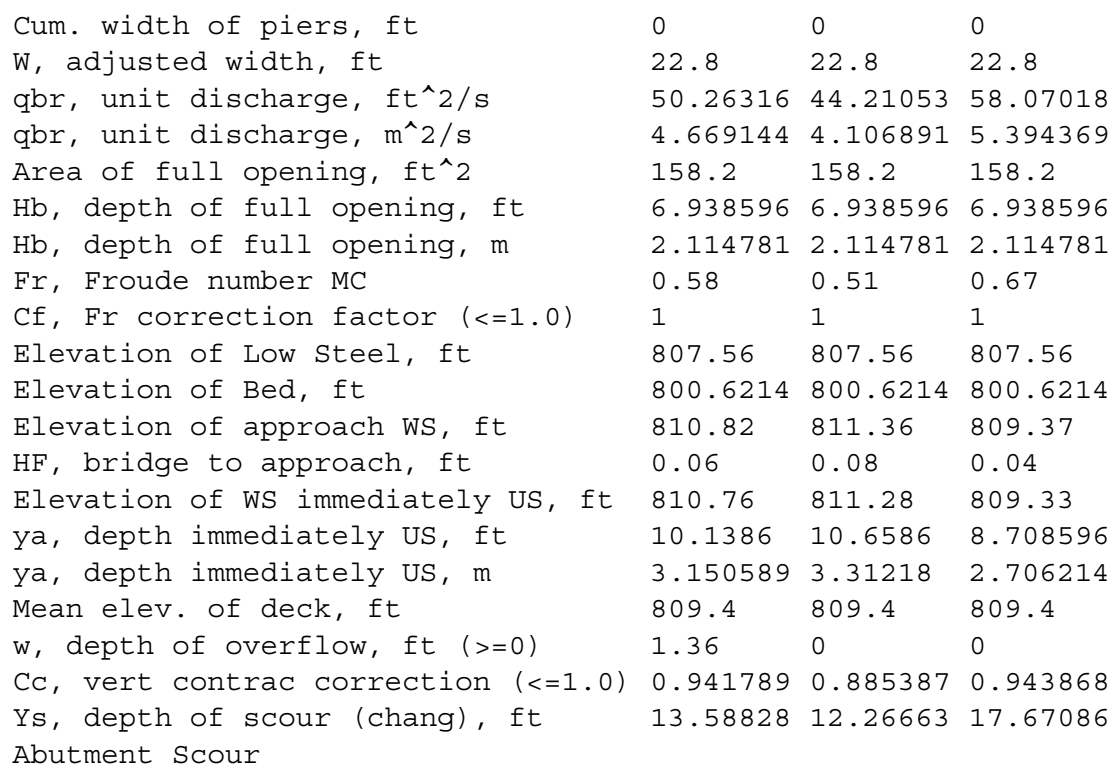

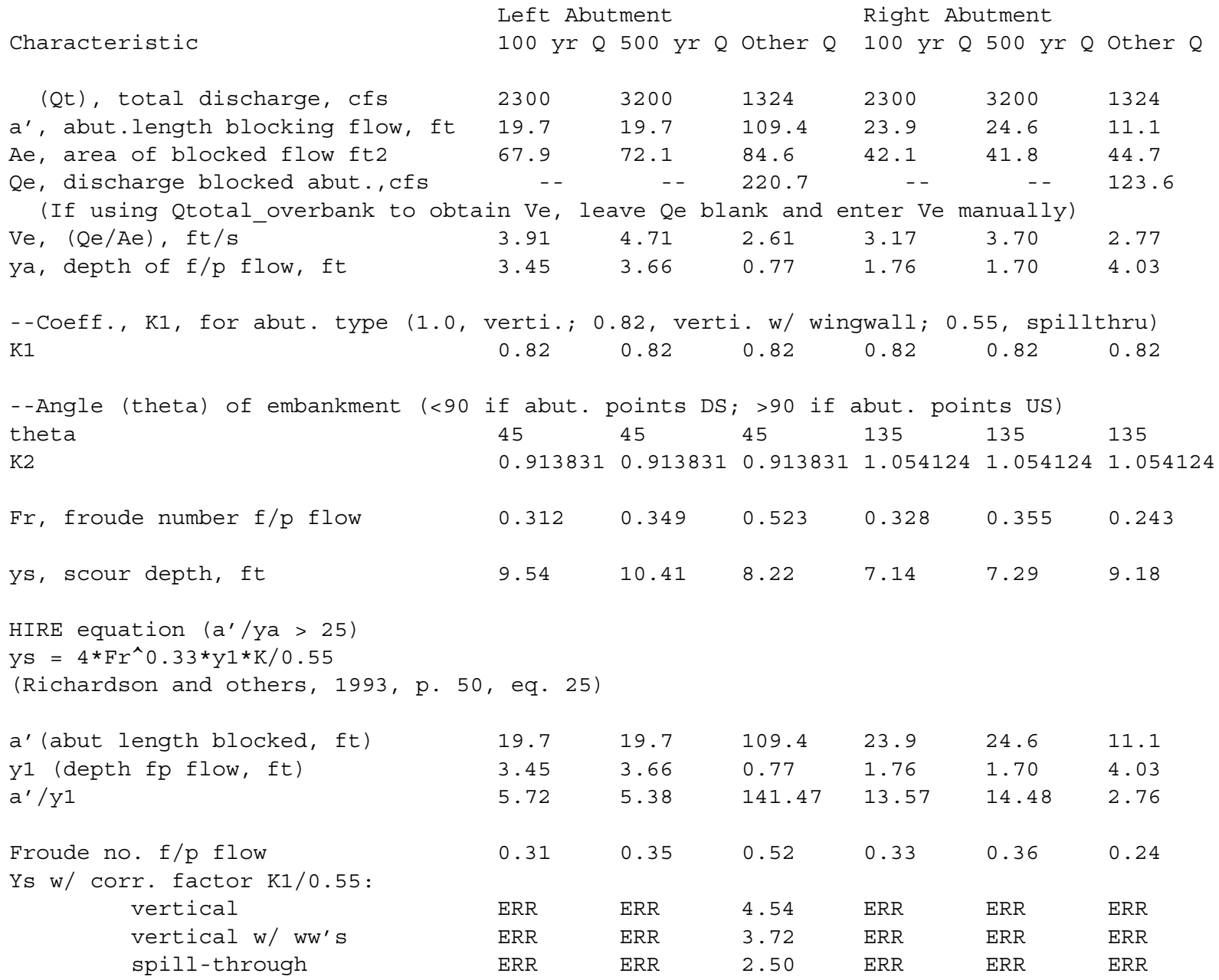




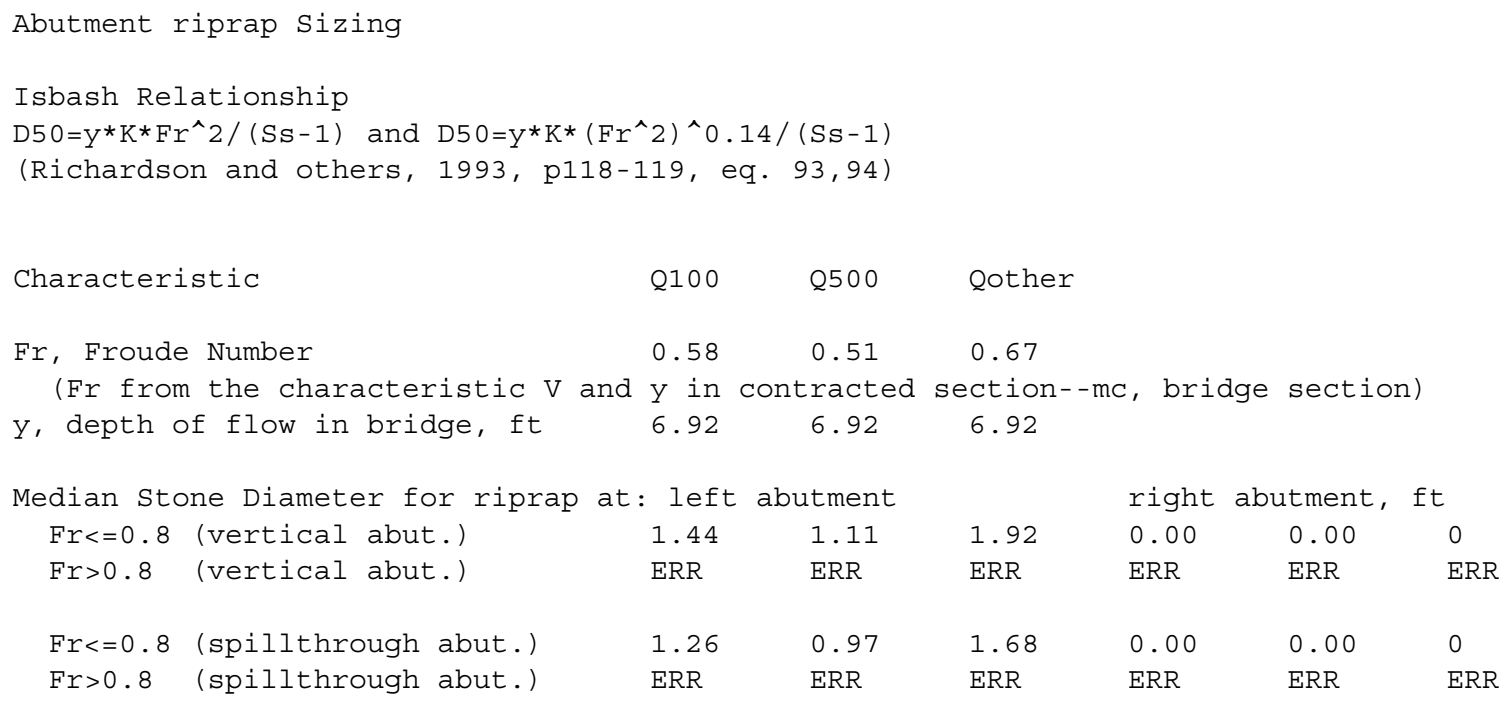




\section{APPENDIX G: \\ POST AUGUST 5-6, 1995 FLOOD DATA FOR STRUCTURE HARDELMSTR0042}


This appendix shows plots of pre- and post- flood channel surveys in the vicinity of Bridge 42 on Elm Street crossing Cooper Brook, in Hardwick, Vermont. Also included are photos from August 17, 1995 (after the flood event).
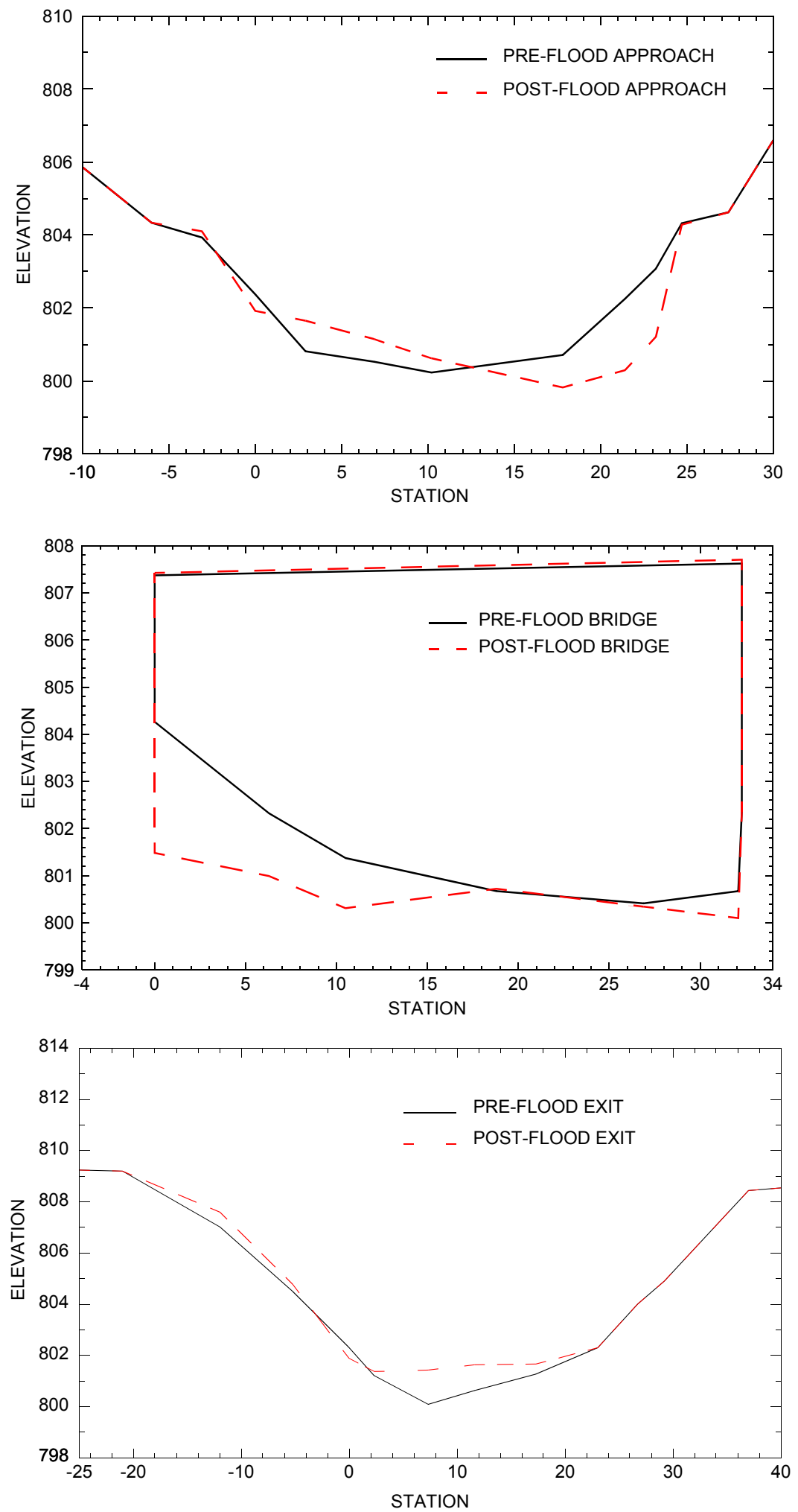

Figure G-1. Pre- (July 24, 1995) and post-flood (August 8, 1995) surveys of three cross sections in the vicinity of Hardwick bridge 42 on Elm Street, Hardwick, Vermont. 


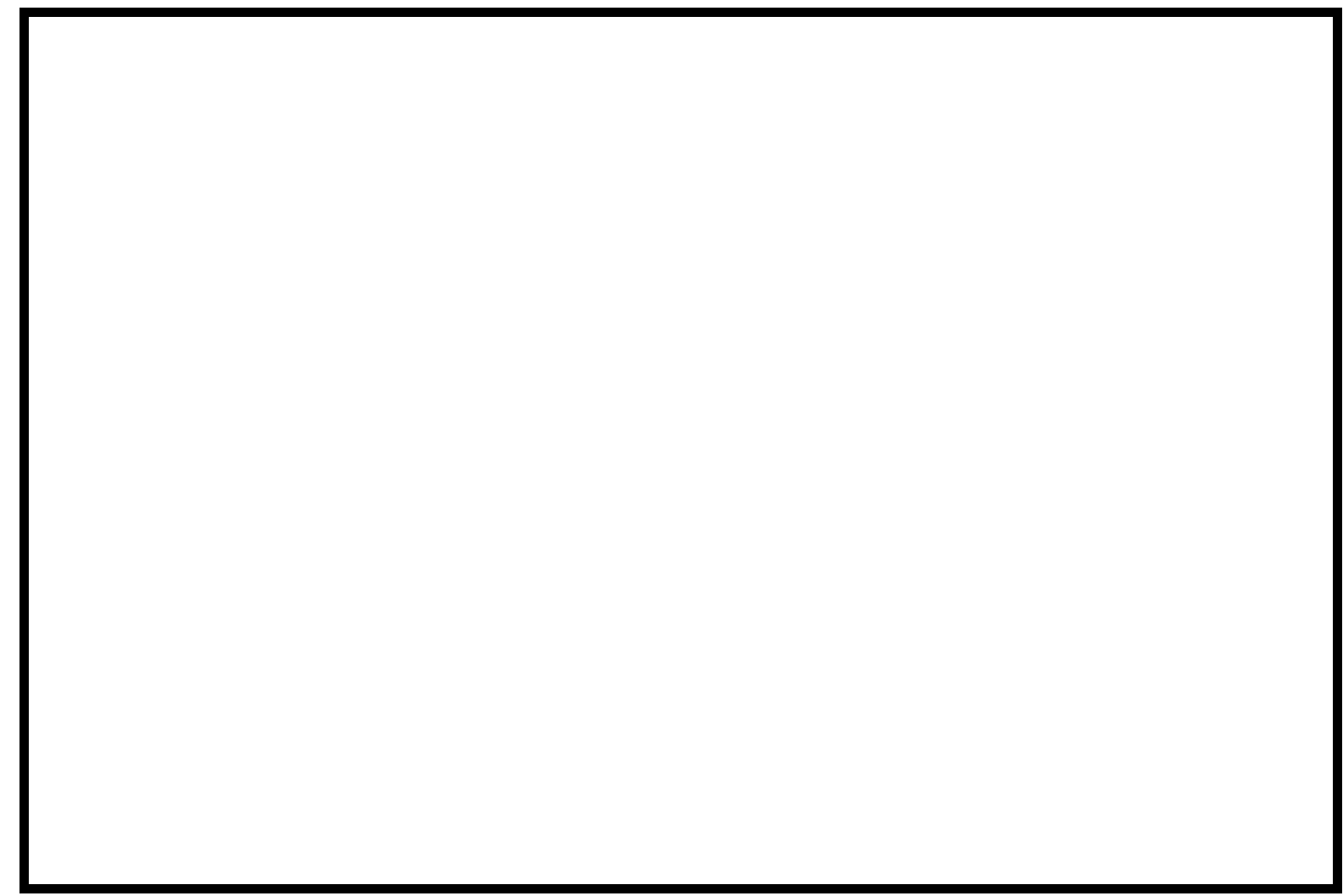

Figure G-2. Structure HARDELMSTR0042 viewed from upstream (August 17, 1995).

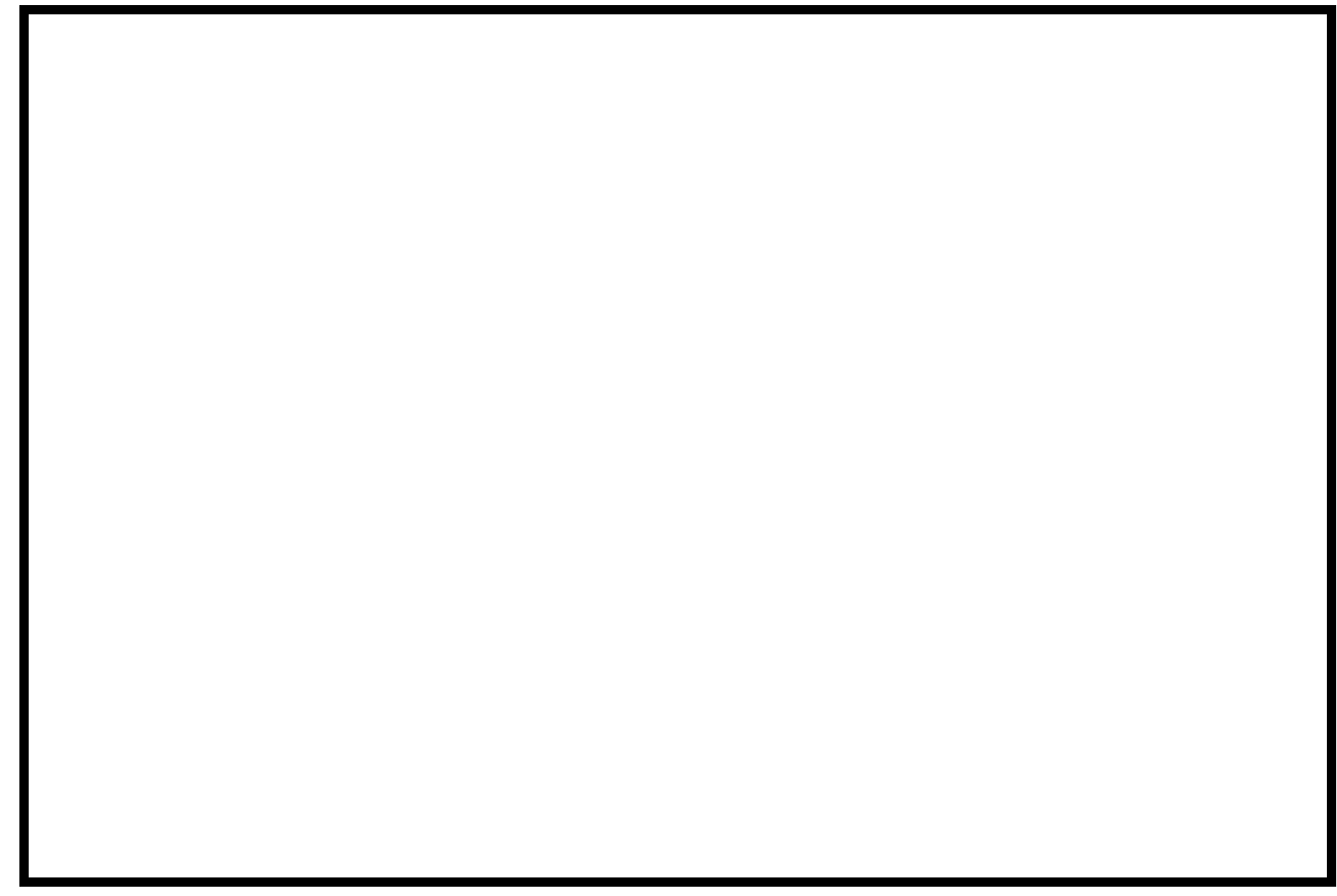

Figure G-3. Downstream channel viewed from structure HARDELMSTR0042 (August 17, 1995). 


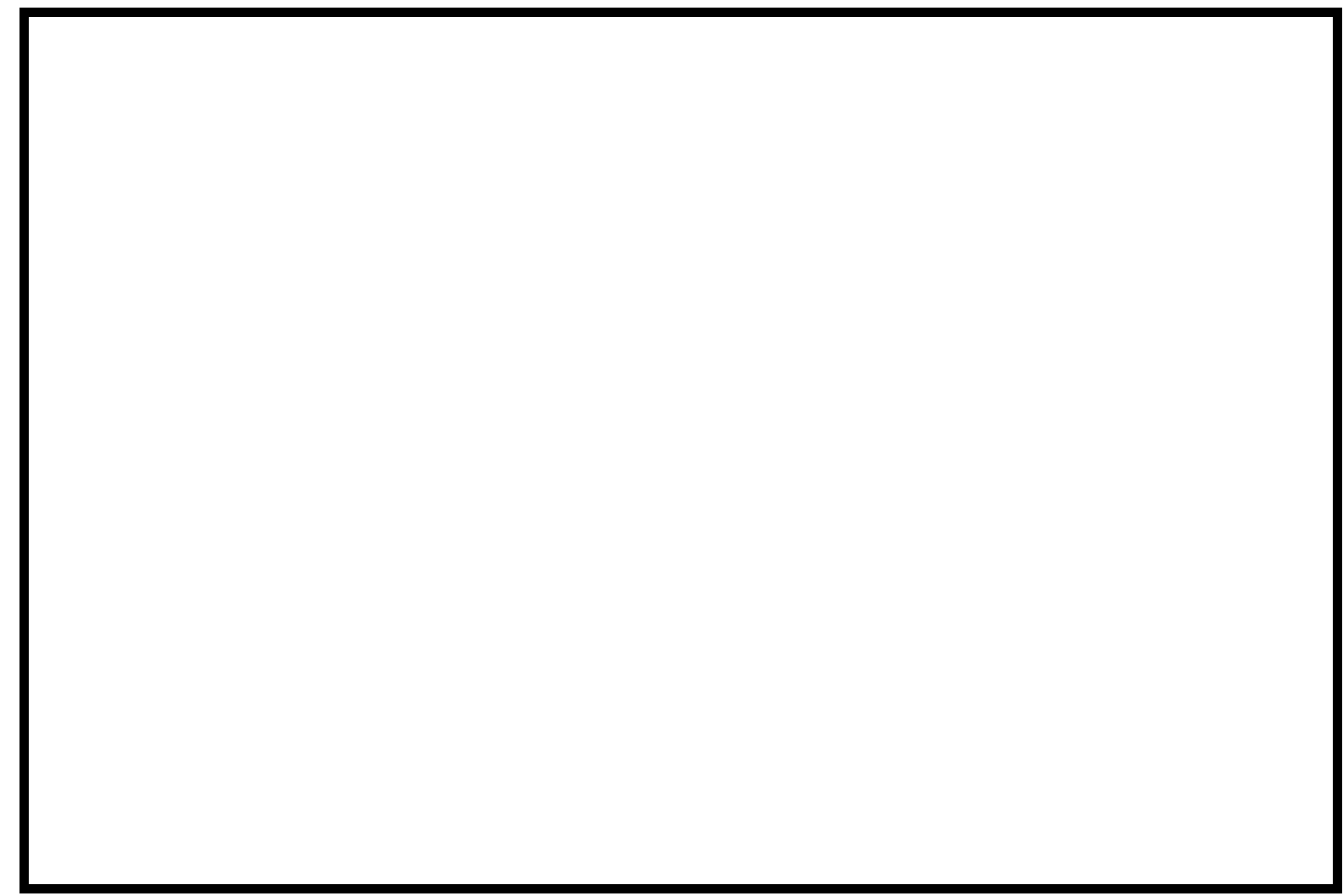

Figure G-4. Structure HARDELMSTR0042 viewed from downstream (August 17, 1995).

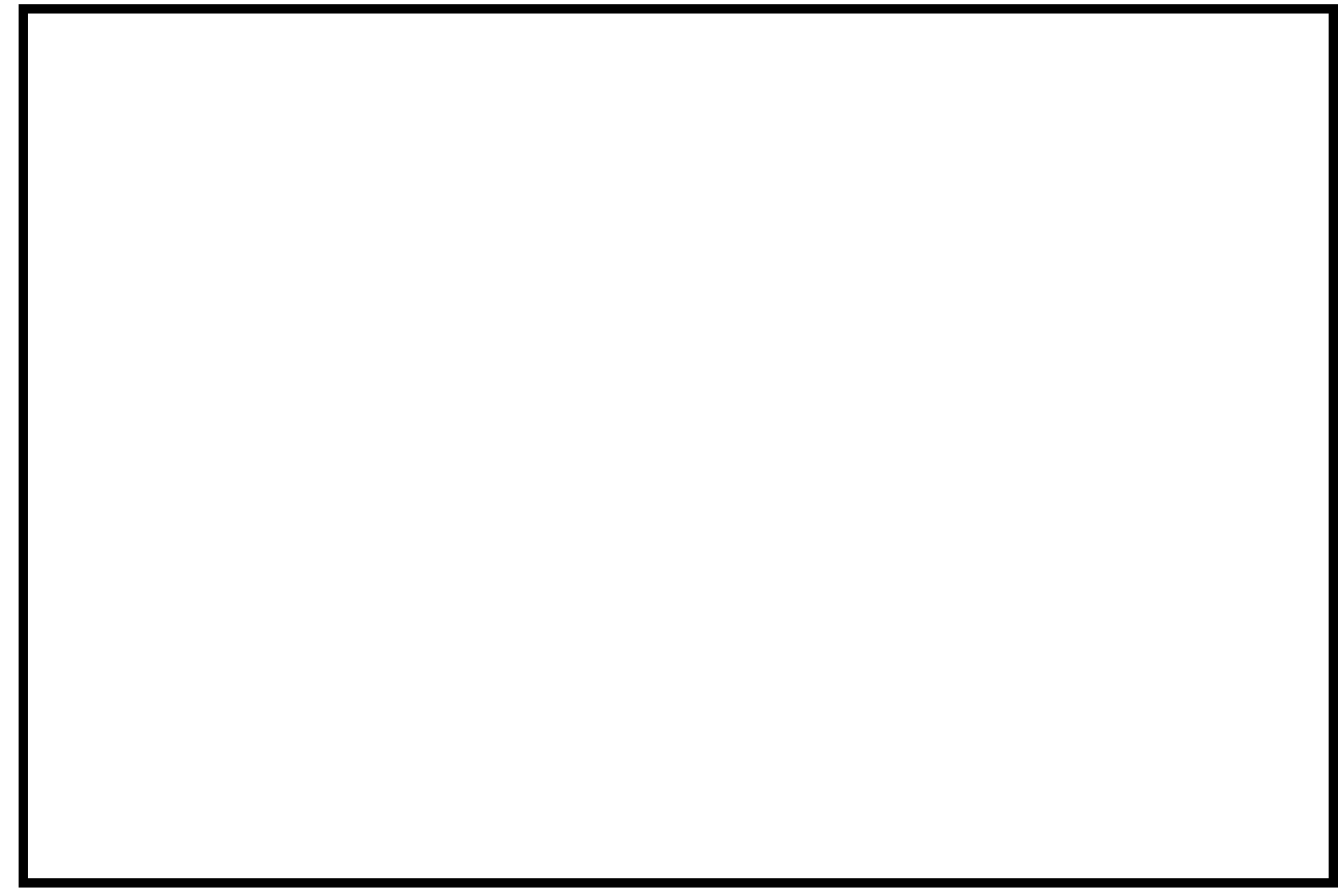

Figure G-5. Upstream channel viewed from structure HARDELMSTR0042 (August 17, 1995). 